NBER WORKING PAPER SERIES

THE ROLE OF FOREIGN CURRENCY DEBT IN FINANCIAL CRISES:

$1880-1913$ vs. $1972-1997$

Michael D. Bordo

Christopher M. Meissner

Working Paper 11897

http://www.nber.org/papers/w11897

\author{
NATIONAL BUREAU OF ECONOMIC RESEARCH \\ 1050 Massachusetts Avenue \\ Cambridge, MA 02138 \\ December 2005
}

The views expressed herein are those of the author(s) and do not necessarily reflect the views of the National Bureau of Economic Research.

(C)2005 by Michael D. Bordo and Christopher M. Meissner. All rights reserved. Short sections of text, not to exceed two paragraphs, may be quoted without explicit permission provided that full credit, including () notice, is given to the source. 
The Role of Foreign Currency Debt in Financial Crises: 1880-1913 vs. 1972-1997

Michael D. Bordo and Christopher M. Meissner

NBER Working Paper No. 11897

December 2005

JEL No. N1, N2, E5, F3

\begin{abstract}
What is the role of foreign currency debt in precipitating financial crises? In this paper we compare the 1880 to 1913 period to recent experience. We examine debt crises, currency crises, banking crises and the interrelation between these varieties of crises. We pay special attention to the role of hard currency debt, currency mismatches and debt intolerance. We find fairly robust evidence that high exposure to foreign currency debt does not necessarily lead to a high chance of having a debt crisis, currency crisis, or a banking crisis. A key finding is some countries do not suffer from great financial fragility despite high exposure to original sin. In the nineteenth century, the British offshoots and Scandinavia generally avoided severe financial meltdowns while today many advanced countries have high original sin but have had few financial crises. The common denominator in both periods is that currency mismatches matter. A strong reserve position or high exports relative to hard currency liabilities helps decrease the likelihood of a debt crisis, currency crisis or a banking crisis. This strengthens the evidence for the hypothesis that foreign currency debt is dangerous when mismanaged. We discuss the robustness of these results and make some general comparisons based on this evidence from over 60 years of intense international capital market integration.
\end{abstract}

Michael D. Bordo

Department of Economics

New Jersey Hall

Rutgers University

New Brunswick, NJ 08901-1284

and NBER

bordo@fas-econ.rutgers.edu

Christopher M. Meissner

Faculty of Economics and Politics

University of Cambridge

Austin Robinson Building

Sidgwick Avenue

Cambridge CB3 9DD

ENGLAND

cm331@hermes.cam.ac.uk 


\title{
The Role of Foreign Currency Debt in Financial Crises: 1880-1913 vs. 1972-1997*
}

\author{
December 5, 2005 \\ Michael D. Bordo \\ Rutgers University and NBER \\ Christopher M. Meissner \\ University of Cambridge, King's College and NBER
}

\begin{abstract}
What is the role of foreign currency debt in precipitating financial crises? In this paper we compare the 1880 to 1913 period to recent experience. We examine debt crises, currency crises, banking crises and the interrelation between these varieties of crises. We pay special attention to the role of hard currency debt, currency mismatches and debt intolerance. We find fairly robust evidence that high exposure to foreign currency debt does not necessarily lead to a high chance of having a debt crisis, currency crisis, or a banking crisis. A key finding is some countries do not suffer from great financial fragility despite high exposure to original sin. In the nineteenth century, the British offshoots and Scandinavia generally avoided severe financial meltdowns while today many advanced countries have high original sin but have had few financial crises. The common denominator in both periods is that currency mismatches matter. A strong reserve position or high exports relative to hard currency liabilities helps decrease the likelihood of a debt crisis, currency crisis or a banking crisis. This strengthens the evidence for the hypothesis that foreign currency debt is dangerous when mis-managed. We discuss the robustness of these results and make some general comparisons based on this evidence from over 60 years of intense international capital market integration.
\end{abstract}

\section{Introduction}

The period from 1870-1913 was a period of globalization in both goods and financial markets comparable to the present era of globalization. It was also a period rife with emerging market financial crises with great resonance for the experience that we have observed in the past decade. In both eras many emerging countries faced frequent currency crises, banking crises and twin crises. They also faced a number of

\footnotetext{
*We thank Antonio David and Wagner Dada for excellent research assistance. Comments from Mario Blejer, Luis Catão, Carlo Cottarelli, Barry Eichengreen, Marc Flandreau, Daniel Lederman, Kim Oosterlinck, Anna Schwartz and participants at conferences at Humboldt University Berlin, the Bank of England, the Emerging Markets Finance conference at Cass Business School, NBER Summer Institute, the 2005 Dubrovnik Economic Conference, and the IMF are also appreciated. Errors remain our responsibility. The financial assistance from ESRC grant RES 000-22-0001 and ESRC World Economy and Finance Programme grant RES-156-25-0014 is gratefully acknowledged.
} 
debt crises coming on the heels of banking and currency trouble. In both periods many of these countries suffered from what Eichengreen and Hausmann (1999) refer to as original sin. The external debt that they accumulated to finance their development was almost strictly denominated in foreign currency or in terms of gold (or had gold clauses) before 1914, just as emerging market debt today is almost entirely denominated in dollars, euros or yen. When the exchange rate depreciates, debt service in gold or foreign currency becomes very difficult leading to an increased likelihood of default, the consequent drying up of external funding and economic collapse.

The emerging country experience stands in contrast to that of the advanced core countries which are financially mature, have credibility and either issue bonds denominated in terms of their own currency or manage their significant hard currency debt carefully. There were few crises in these countries. This leads us to wonder whether these debt structures might play a role in explaining the difference in crisis incidence. We also investigate whether balance sheet mismatches as discussed in Goldstein and Turner (2004) mattered. Finally we also examine whether poor reputation and accumulated default experience was a problem as hypothesized by Carmen Reinhart, Kenneth Rogoff and Miguel Savastano (2003) in their work on debt intolerance.

We have developed a database to allow us to identify and distinguish original sin and balance sheet crises from more traditional currency and banking crises for roughly 30 countries (both advanced and emerging) from 1880-1913 and over 40 countries between 1972 and 1997 the post-Bretton Woods period. We have data both on type of crisis incidence and on the fundamentals that economists believe are determinants of crises. A caveat worth keeping in mind is that the original sin data and our mismatch data especially in the recent period are highly incomplete and researchers still lack the coverage necessary to make definitive conclusions. Our data set then is somewhat unique in that the coverage and quality of the available data from 100 years ago are somewhat better than contemporary data. Nevertheless, we use the data of limited quality to estimate the probability of having a particular type of crisis using standard pooled probit models so as to show the correlation between original sin, mismatch and financial crises.

Our results do not find unambiguous support for the idea that hard currency debt is always associated with more financial turbulence. Good financial management 
of the original sin condition, strong financial development and agile responsiveness to crises seem to play a role in helping avoid crises. In fact, we find evidence that countries with significant or full-blown original sin can be divided into two subgroups. For example in the pre-1914 period, one group includes countries such as Argentina, Brazil, Chile, Italy and Portugal each of which suffered a financial catastrophe between 1880 and 1913. The other group, including Australia, Canada, New Zealand, Norway, and the US had relatively little trouble with financial crises in terms of frequency or virulence.

We argue that today countries like Greece, Ireland, Israel, Spain, Sweden, and Singapore look similar to the latter set. On the other hand, countries like Argentina, Malaysia, Thailand, Indonesia and Brazil which suffer from financial fragility, manifested by more frequent and more encompassing crises, look like the former set of the nineteenth century. Today, measured original sin in both groups of countries is high, but crisis incidence has been much lower in the first set of countries.

We ascribe this partially to good debt management or avoidance of currency mismatches on the aggregate balance sheet and partially to special country characteristics that vary over time and are most difficult to control for econometrically. The latter group of countries do not seem to possess either of these strengths. We also argue there are two other sets of countries. One consists of the most peripheral regions. These suffer from original sin, but they are closed to international capital flows and hence have been more successful at avoiding crises. The other includes the most advanced economies without original sin, strong financial systems and infrequent currency and debt crises.

This is a more extensive categorization than simply core versus periphery or industrialized vs. emerging market. It also highlights the fact that original sin is not always associated with financial crises. Some countries are able to avoid the vicious cycle of exchange rate depreciation and balance sheet deterioration that often leads to financial catastrophe. Others seem unable to do so. Some countries are financially robust while others are overwhelmingly vulnerable. This categorization seems to be evident in the two historically distinct periods of financial globalization. It moves us closer to understanding which country characteristics interact with original sin so as to produce financial fragility. Conditioning on observables and allowing for unobservable heterogeneity in the ability to deal with and withstand crises leads us to the conclusion that there is substantial evidence that careful debt management matters 
when original sin is a fact of life. When countries match their hard currency liabilities with hard currency reserves or take out such debt in proportion to their export earning potential, they reduce their exposure to currency and banking crises which often can spill over into debt crises in the presence of balance sheet effects. Finally we sound a note of caution. Since many of our comparative results are based on data that are limited in coverage and different in scope, we discuss the vital need for further research and data collection efforts to maximize the information available from the historical record.

\section{History, Financial Crises, Balance Sheets and Hard Currency Debt}

In this paper we view banking trouble, currency crises and debt crises that occur in the same or consecutive years as inter-related phenomena. This is different from first generation currency crisis models that viewed them as events arising from unsustainable fiscal policy under a pegged exchange rate. It is also different from a strand of the literature which views banking crises as arising uniquely from poor supervision, weak structure or stochastic liquidity runs. Our view is that while some countries had crises that unfolded in ways the older generation of models would predict, other countries faced financial meltdown by having twin (banking and currency crises) or even triple crises, where in addition to a large depreciation and disruption in the banking sector sovereign debt went into default.

One important factor determining the ultimate outcome may be an interaction between the nature of the debt contracts in place and the robustness of the financial system. Our framework for thinking about financial crises is very much parallel to that enunciated in Mishkin (2003) which in turn is inspired by an open-economy approach to the credit channel transmission mechanism of monetary policy. Balance sheets, net worth and informational asymmetries are key ingredients in this type of a model.

Initial trouble might begin in the banking sector for a number of reasons. One possibility is that international interest rates rise. This worsens the balance sheets of non-financial firms and banks alike. As the number of non-performing loans rises and net worth falls, a decline in lending can occur contributing further to output losses. At this point, internationally mobile capital may take a decidedly pessimistic view of 
returns in the debtor country and either stop coming in (a sudden stop) or reverse itself leaving significant short-term financing gaps.

This reversal leads to more trouble in the financial sector and increased stress for non-financial firms which are forced to cut investment because of the lack of financing. Governments may have trouble making interest payments on debt coming due as capital markets become unwilling to continue rolling debt over. The capital flow reversal, if large enough, could also force the abandonment of an exchange rate peg and a large change in the nominal exchange rate. Floating regimes could also see large depreciation occur under such a scenario.

A view inspired by the events of the late 1990s regarding the impact of such exchange rate changes is that they may be contractionary. ${ }^{1}$ This is where original sin enters the picture. Since the majority of obligations for nearly all countries are in foreign currency or, in the late nineteenth century, denominated in terms of a fixed amount of gold, depreciation vis-à-vis creditor countries or breaking the link between gold and the domestic currency could lead to increases in the real value of debt. This is a redistribution of wealth from domestic borrowers to their creditors who are expecting a certain amount of gold or foreign currency. ${ }^{2}$ When net worth matters for lending decisions, this decline in the net worth of debtors can lead to another round of "disintermediation" causing widespread bankruptcies due to liquidity problems. All else equal, the deterioration to debtors' balance sheets would be more severe the greater the amount of fixed interest rate hard currency debt outstanding.

There is some contention in the literature as to whether all is in fact equal. Goldstein and Turner (2003) have argued that often countries insure themselves against exchange rate movements. Hard currency debt can be backed up by hard currency assets. Alternatively, countries could have enough export capacity to offset changes in liabilities due to exchange rate swings. To gauge the actual effect of original sin one must take account of the mismatch position or the entire balance sheet

\footnotetext{
${ }^{1}$ Theoretical work by Céspedes, Chang and Velasco (2004) demonstrates how under certain very plausible circumstances original sin can lead to contractionary depreciations. They also point out that multiple factors matter for how depreciations interact with economic fluctuations. These are: the level of original sin, the level of indebtedness, openness to trade and the degree of financial friction. Their theoretical model divides countries into a financially robust region and a financially vulnerable region. The latter experience contractionary depreciations.

${ }^{2}$ Eichengreen, Hausmann and Panizza (2003) argue that what matters is the aggregate external mismatch and if all debt is domestic, that one sector's losses are the others' gains. Our view however is that net worth matters. When a debtor's net worth deteriorates, borrowing capacity falls, and the capital markets seize up. This is one reason why we should focus on domestic and external hard currency debt rather than just foreign holdings (or issues) of hard currency debt.
} 
position of an economy. We describe how we do this below. Moreover, Reinhart, Rogoff and Savastano (2003) have argued that original sin is a proxy for a weak financial system and poor fiscal control. As we describe below, we control for some of these fundamentals too, allowing for a test of this competing hypothesis.

\section{$\underline{\text { 2.1 The Role of Original Sin }}$}

It has been the case since at least the $18^{\text {th }}$ century that debt issued on international capital markets has been denominated in the currency of the market of issue and not the currency of the issuing country. In fact a large amount of locally issued debt was payable in a fixed amount of gold and today is indexed or made payable in foreign currencies. It has also long been noted that such debt can become more onerous to repay in the face of depreciations, and that since emerging markets often face rapid exchange rate depreciations associated with sudden stops and reversals of capital inflows or very loose monetary policy, these countries are more often the victims of such a volatile combination.

Over the last ten years, these phenomena have started to be addressed in the economics literature. Eichengreen and Hausmann (1997) argued that the danger of exchange rate fluctuations in the face of foreign currency borrowing might oblige many countries to adopt hard currency pegs. They coined the term "original sin" because they argued foreign currency denominated debt was imposed by international capital markets. Nations with poor reputations, and even nations with good reputations or solid fundamentals, are obliged to issue debt in key international currencies. In other words, domestic policies or problems were not the only reason countries could not borrow in their own currencies. Because of "original sin" and the problems that could be generated in the face of a devaluation, Eichengreen and Hausmann (1999) argued that exchange rate policy was of the utmost importance even for those countries where fundamentals and fiscal policies were sound but which might fall victim to a liquidity run.

One key controversy remains. Exactly how harmful is original sin? Early work by Eichengreen and Hausmann used mainly anecdotal evidence both on the incidence of original sin and its effects. Very recent work by the same authors along with Ugo Panizza (Eichengreen, Hausmann and Panizza 2005) has shown that countries with 
higher original sin have higher exchange rate volatility and higher macroeconomic volatility. Flandreau (2003) argues that in the nineteenth century depreciation increased the debt burden because of original sin which led to sovereign debt crises. He illustrates this with reference to several cases. But we are unaware of any work which has attempted to find a systematic empirical association between original sin and financial crises either in the past or for the period between 1972 and $1997 .^{3}$

For the historical period, we collected data from various national sources on hard currency debt and augmented and compared this with data made available by Flandreau and Zúmer (2004). What we refer to as hard currency debt is debt that carried a gold clause or was made payable at a fixed rate in a foreign currency. ${ }^{4}$ Our measure of original sin is the ratio of this quantity to total public debt outstanding.

This measure is different from the measure we use for the 1972-1997 period. For this period we use the measure of original sin defined in Eichengreen Hausmann, and Panizza (2005). This measure of international original sin for country $i$ based on securities issued by residents and non-residents internationally is $O S_{i}=\max \left(1-\frac{\text { Securities issued in currency } \mathrm{i}}{\text { Securities issued by country } \mathrm{i}}, 0\right) .5$

We must be clear that there is a potential problem in the original sin data. It is only available for the period 1993-1997. We calculate the within country average of the observations available. We then use this average value for all the years in which a country appears in the data set. This broadens the time span of our sample, but obviously creates some measurement error in our key explanatory variable and complicates any "within-style" regressions. We are confident that the bias imparted is

\footnotetext{
${ }^{3}$ Our conclusions differ from Flandreau's as we take on a wider set of hypotheses and cases. Empirical work by Flandreau and Zúmer (2004) which regresses sovereign bond yields on a ratio of interest service to government revenues and a number of other variables also argues that hard currency or gold debt was dangerous. Their tests are quite different from ours since our dependent variables are debt crises, banking crises, or currency crises. Frankel and Rose (1996) examined "currency crashes," external debt and exchange rate fluctuations, but their approach to measuring original sin, its impact and the type of crises considered is different than ours. Specifically, they look at the transmission of shocks from the core through the interest rate on foreign currency debt.

${ }^{4}$ The data appendix from Bordo and Meissner (forthcoming) has more to say about the structure of this debt. Flandreau and Zúmer (2004) highlight just some of the difficulties in defining this type of debt. Italian bonds for example had de facto gold clauses for foreigners but not for residents, but de jure gold clauses for both classes of creditors for a certain proportion of the debt. Likewise, Spain arbitrarily implemented a residency distinction for manner of repayment around 1900. US debt was sometimes vague ex ante about the terms of repayment and often repayment was promised "in specie". Mostly this was meant to be gold but could have meant silver which secularly depreciated against gold after 1873. Still our measure is at least a good proxy for the variable of interest.

${ }^{5}$ For the 1972-1997 period this measure runs from 0 to 100 while for the historical period it is based on the 0 to 1 scale.
} 
not too severe. This relies on the fact that original sin is extremely slow to move over time and for most countries it does not move from 100 over the observation period. Figures below show this country by country and qualitative evidence by Eichengreen et. al. make this assertion seem reasonable. ${ }^{6}$

One key difference between markets today and in the nineteenth century is that recently debt has been issued in quite a few small country currencies by agents from leading countries allowing opportunities for debt swaps. That is, for some countries, the numerator and the denominator in the difference term differ substantially because many other countries issue debt in their currency. To the best of our knowledge it does not appear that foreigners pre-1914 were issuing debt in other exotic currencies. In the pre-1914 case, original sin was not reduced through swaps (Flandreau 2003 p. 20) hence we can restrict attention in the numerator of this expression to securities issued in local currency (without gold clauses) only by residents.

The other key difference between our nineteenth century measure and the contemporary measure that we use is that in the historical period we look at debt issued in domestic and international markets instead of looking only at international issues. One reason we view this as important is because many domestic issues of the day carried gold clauses. As described above, in the case where monetary authorities devalued the local currency in terms of gold this would have an effect similar to a depreciation when a country had foreign currency debt. In either event, real debt repayments for local currency gold clause debt and for foreign currency debt would both increase. ${ }^{7}$ Hence, in the early period we do not classify debt as "debt issued in (local) currency $i$ " if it contained a "gold clause" stipulating a fixed quantity of gold per unit of local currency payable. Only debt payable in local paper currency, without mention of the gold-local currency exchange rate upon payment of coupons and principal, is included in the ratio above. The latter period data leaves out domestically issued debt.

\footnotetext{
${ }^{6}$ Australia, Canada and South Africa saw large declines in their original sin measures over the 1980s. Because of this we understate their measures in the 1970s. In the econometrics this is likely to lead to slight upward bias of the positive effect of original sin on crisis incidence since these countries had few crises but actually had high original sin.

${ }^{7} \mathrm{We}$ are finessing the question of what happens to the real exchange rate and prices in general. We assume here that nominal depreciations are equivalent to real depreciations in the short-run perhaps because of sticky prices. On the domestic side, we assume going off gold or a depreciation implies a depreciation of the local currency versus gold and domestic prices are constant over the short run.
} 
The question then arises of how related our measures are in the two periods, and this hinges on how domestic original sin relates to international original sin. Unfortunately there is not much data available to answer this question. Eichengreen, Hausman and Panizza (2003) collected data for two dozen countries and show that in several of these, domestic original sin diverges distinctly from the level of original sin. But for the most part, original sin and domestic original sin are highly correlated and so we are comfortable using the international measure. ${ }^{8}$

Figure 1 shows the ratio of hard currency government debt to total government debt by country between 1880 and 1913 . Our time series plots reveal most countries' measure of original sin to be fairly constant over time. Some countries' situations "worsened". In the nineteenth century, Japan became more exposed to foreign currency debt as it entered global capital markets from the late 1890s. Argentina and Brazil converted local currency paper debt into gold clause debt in the 1890s. Only Spain and Italy appear to have decidedly decreased their reliance on hard currency debt relative to internal currency debt. These nations often had floating currencies throughout the period. As noted by Flandreau and Sussman (2005), their situations appear similar to those of Russia and Austria-Hungary, countries which had relatively low degrees of original sin and which also had floating currencies over most of the period we cover. These are the counter-examples to those who believe that poor fiscal history, a shaky exchange rate policy and economic backwardness are causes of original sin. Nearly all of these countries had previous episodes of debt default and chronically poor fiscal situations.

Figure 2 shows the evolution of the original sin measure for various countries between 1993 and 1997. We also see the strong persistence in the original sin measure over these five years. Only Denmark, New Zealand and South Africa seem to have large changes in original sin while a few other developed countries have mild changes. The less developed countries and the emerging markets seem to have little change.

Figure 3 shows the long-run averages in the nineteenth century of our original sin measure. This also reveals a counterintuitive ranking, but is consistent with previous findings by Flandreau and Sussman (2005) and Eichengreen, Hausmann and

\footnotetext{
${ }^{8}$ The share of each kind of debt (domestic and external issues) will also obviously matter. This could be one reason why we find that more developed countries with larger pools of domestic savings and larger domestic debt markets are able to deal with measures of original sin that are quite high.
} 
Panizza (2005). Financial centers have less original sin. Small peripheral countries have a lot of original sin. Countries with ostensibly rotten fiscal institutions and poor international track records have intermediate levels of original sin. Notice that Spain, Russia, Austria-Hungary, Italy and Argentina are all towards the lower middle of the spectrum. However, some countries with sound fiscal, financial and monetary records, like Denmark and Sweden also fall into this range. These countries, had financial institutions that were evolving in the same direction as the core. ${ }^{9}$

Figure 4 displays the 1993-1997 within country averages of original sin. Again, a counter-intuitive ranking comes forth if one believes that poor financial development and a lack of credibility matter for original sin. Amongst the countries with measures of original sin between 80 and 100, we see highly developed countries such as Belgium, Finland, Ireland, Singapore and Sweden. At the same time, nearly all emerging markets except perhaps South Africa also have high levels of original sin. Figures 3 and 4 then provoke the question: are fundamentals (both those directly observable and those that are less easy to systematically operationalize) more important for explaining crisis incidence than the actual level of hard currency debt or original sin?

\subsection{Currency Mismatches}

Goldstein and Turner (2004) have argued that currency "mismatches" are the main potential problem with foreign currency debt. Countries that have foreign currency liabilities which are not offset by foreign currency assets may be more likely than countries with more foreign assets to find it difficult to repay their foreign currency debts in the event of a depreciation. On the margin, changes in the exchange rate can become a problem the greater the mismatch as local currency assets lose value in terms of the foreign liabilities. Goldstein and Turner have three key ingredients to their overall measure of a nation's mismatch. They first use the difference between all reported foreign assets and foreign currency liabilities outstanding. They then divide this measure by exports (or imports if the difference is

\footnotetext{
${ }^{9}$ In Bordo and Meissner (2005) we discuss the qualitative and historical evidence on the evolution of original sin and present several case studies of crisis experiences.
} 
positive) to account for openness to trade. ${ }^{10}$ For example, (when positive) the mismatch decreases with exports because a depreciation would likely attract a larger amount of extra foreign currency resources available to the domestic economy and thus such a country would be more naturally hedged. Finally they pre-multiply this ratio by the ratio of all reported foreign currency liabilities to all reported liabilities outstanding.

Data on government and non-government foreign assets is difficult to assemble today and probably impossible for the pre-World War I era. In the nineteenth century, we focus on the government's mismatch and believe this is a relatively good proxy for the economy-wide mismatch. The functional form we choose is different from Goldstein and Turner and slightly closer to that used in Eichengreen, Hausmann and Panizza (2003). ${ }^{11}$ For country $i$ we have

$$
\text { Mismatch }_{\mathrm{i}}=\frac{\text { total hard currency debt outstanding }- \text { international reserves }}{\text { exports }}
$$

For the nineteenth century, our measure of reserves usually only includes gold reserves held at the central bank, in the banking system or held by the government treasury. The sources are listed in the appendix to Bordo and Meissner (2005). For the twentieth century we use international reserves as given in data underlying Bordo et. al. (2001).

For the twentieth century, we use the total of external debt given in the World Bank's Global Development Finance or the level of external debt given by the IMF's International Financial Statistics for countries not listed in the former. For the nineteenth century, total hard currency debt (domestic and international issues) is

\footnotetext{
${ }^{10}$ Goldstein and Turner choose a functional form so that the boost to exports from a depreciation improves a nation's balance sheet. Though the Goldstein and Turner metric (and our version of theirs) is one measure of the balance sheet position, it is not the ideal measure of a nation's balance sheet. There are omitted ingredients that could make a difference to the balance sheet. For example, for this period, one could theoretically refine this measure by including foreign currency and gold revenues collected through tariffs, and perhaps foreign assets held in banks. Most of these data would be impossible to collect for a reasonable number of observations. Functional form is also something for future research. For comparability we choose a measure as close to the Goldstein and Turner form as possible.

${ }^{11}$ Eichengreen Hausmann and Panizza (2003) report that the correlation between their measure of mismatch and the Goldstein and Turner measure is 0.82 .
} 
calculated directly if the data is available or by multiplying the total debt outstanding by the percentage of total debt that is payable in gold or foreign currencies. ${ }^{12} \mathrm{~A}$ priori, a higher mismatch measure should be correlated with more financial crises. As such it compares with the Goldstein and Turner measure. Nevertheless, it does take a slightly different functional form and potentially does leave out a significant fraction of total assets and liabilities in the economy. The median of our twentieth century mismatch measure is 0.95 with a standard deviation of 1.3 . In the nineteenth century the values are 0.79 and 2.66 .

\subsection{Debt Intolerance}

A new literature on sovereign financial difficulties has emphasized the role of past defaults in creating current difficulties. Reinhart, Rogoff and Savastano (2003) (RRS) have coined the term debt intolerance. This line of research tries to explain why some countries are able to sustain very high debt to GDP ratios while other emerging market countries run into debt problems with comparatively low debt to GDP ratios. Their evidence suggests that past defaults generate poor sovereign ratings. Countries with worse track records in international capital markets suffer greater financial fragility due to increased borrowing costs at a given level of debt to GDP. An alternative view might be that default history or sovereign ratings are proxies for other underlying structural or institutional problems. Hence we would also like to control for such fundamentals, as far as possible, to allow for the possibility of graduation from debt intolerance.

Given these hypotheses, we would like our tests to include a measure of default history. For the nineteenth century sample, we interact a public debt to government revenue ratio with an indicator variable that equals one if a country had at least one default episode between 1800 and 1880 . In the twentieth century sample our debt sustainability measure changes to the debt to output ratio since output data is

\footnotetext{
${ }^{12}$ Goldstein and Turner note that net worth increases with depreciation for net creditors. To get around the fact that an increase in the denominator of mismatch would decrease the mismatch measure for net creditors they divide by imports when assets exceed liabilities. For all of the results we present, we divide by exports. In our nineteenth century sample, we also tried dividing by imports when appropriate. The two measures have a correlation of 0.999 . Our results do not change significantly in that sample when we divide by imports for those observations with positive numerators.
} 
more reliable and our debt measures include more than just government debt. We interact this ratio with an indicator that equals one if there was a default in the country between 1824 and 1971. If the increase in the probability of a financial crisis for a marginal increase in the debt to revenue or debt to GDP ratio is larger for a peripheral country or a past defaulter, we would argue there is evidence in support of the debt intolerance hypothesis.

\subsection{Other Data and Hypotheses}

The literature on predicting financial crises with econometric techniques is abundant. Our approach is inspired by the pared down methodology of Frankel and Rose (1996) who looked at currency crashes at the annual level. Many subsequent papers have made modifications to this early attempt and have largely been unsuccessful at accurately predicting any type of financial crisis with great accuracy. ${ }^{13}$ However, some approaches and explanatory variables have done reasonably well in predicting crises or at least being strongly and statistically significantly correlated with crises in a way consonant with priors based on economic theory. ${ }^{14}$

We attempt to control for the union of the variables from the extant literature that are applicable to the time period at hand. In parentheses we list the variable used in the 1972-1997 period if it varies from that used in the early period. The list includes total outstanding government debt divided by government revenue (debt to GDP), growth in the terms of trade, the trade balance divided by nominal GDP, the domestic long-term interest rate, an indicator for whether the country maintained a gold standard (or a pegged exchange rate), growth of the money supply, the ratio of gold reserves in the banking system to notes in circulation (the ratio of reserves to M2), and the yield on British long-term bonds (the unweighted average of G7 longterm interest rates). ${ }^{15}$ The variables used depend on which type of crisis we are examining and are well indicated in the respective tables. Our sources, and definitions of these variables are located in the data appendix.

\footnotetext{
${ }^{13}$ See Berg and Patillo (1999) for a broad comparison of some important papers in this literature.

${ }^{14}$ Glick and Hutchinson (2001) explore twin crises in emerging markets, and our methodology to gauge the interaction between banking, currency and debt crises in part resembles theirs.

${ }^{15}$ In previous work we used the deviation of the real exchange rate from the period average but this variable is rather ad hoc as it is not a real effective exchange rate. It was not terribly informative and there is a lack of data in the present period so we have dropped it.
} 
A complete list of the included countries for the basic specifications is also found in the data appendix. The specifications from the 1880-1913 sample include roughly 21 countries which were also examined in Bordo, Eichengreen, Klingebiel, and Martínez-Peria (2001). We have added information on crises and macro data for nine other countries. These new additions include Austria-Hungary, Egypt, India, Mexico, New Zealand, Russia, South Africa, Turkey, and Uruguay. However limitations in availability of the macro data prevent all of these countries from appearing in each and every specification. For the 1972-1997 sample, he number of countries that actually appear in the estimations is somewhat counts roughly 36 countries in the typical econometric model.

\subsection{Crises, 1880-1913}

In Figure 5 we present the frequency of various types of crises (banking, currency, twin, debt, "third generation" crises and all types of crisis together). ${ }^{16}$ This is the number of years a country was in crisis divided by total possible years of observation. We use the country-year as the unit of observation and eliminate all country-years that witness ongoing crises from the denominator (except for third generation crises where we do not eliminate ongoing banking and currency crises) to come up with a total number for years of observation. We see the pattern found in Bordo et. al. (2001) in terms of the relative frequency of types of crises. The predominant form of crises before 1914 were banking crises, followed by currency crises, twin and then debt crises. ${ }^{17}$

By comparison, the most recent period seems much more crisis prone measured in any of these several ways. Today the incidence of currency crises is quite high and debt crises accompanied by banking and/or currency crises are much more frequent although still quite uncommon overall.

\footnotetext{
${ }^{16}$ Our crisis dates and the methodology we use to classify years of crisis are listed in the appendix. We define a crisis as "third generation" if there was a debt crisis accompanied by either a banking crisis (ongoing or in the first year) a currency crisis or both in the same or previous year.

${ }^{17}$ Debt crises were not demarcated by Bordo et al. (2001)
} 
Figures $6,7,8$ and 9 present scatter plots of the percentage of time a country was in a crisis episode versus our measure of original sin and our mismatch variables. ${ }^{18}$ In the pre-World War I era, there appears to be an inverse U relationship between debt crises and original sin. Countries with intermediate ranges of original sin seem to take longer to resolve their debt crises than those at either end of the spectrum. No such pattern is evident in the latest period. In fact there appears to be a direct positive relationship between the severity of debt crises and the average level of original sin and similarly for currency and banking crises. But still there is a much larger variance in experience at the upper levels of original sin. This observation raises the possibility that countries manage original sin in very different ways.

Also there appears to be a positive relationship between mismatches and the length of time spent in a debt crisis. At the same time, the scatters in Figures 8 and 9 which feature mismatch on the $\mathrm{x}$-axis seem too chaotic to discern with certainty much of a pattern. Further conditioning is likely to be important.

As to the "quadratic" or inverse $\mathrm{U}$ in the nineteenth century, it seems intuitive that the financial centers which were more economically developed had fewer crises than nations like Russia, Argentina and Italy. But what about the countries with high measures of original sin and a low likelihood of a crisis? These data points include primarily the British offshoots like Australia, Canada, New Zealand and the US but also small European countries like Norway and Finland. This hump-shaped relationship is some (unconditional) evidence that original $\sin$ is not always related to more financial fragility. There are three possibilities that might explain this inverse $U$ pattern. First, some other omitted but observable variable protected these countries from crises. Second, some unmeasured but time invariant factor helped them to avoid crises (e.g., strong institutions or the market's "trust"). Finally there is the possibility that time-variant unobservable factors such as improvements in the financial system or the ability to deal with crises as and when they arose are at play.

One might conjecture that these countries avoided crises because of their strong financial systems and fiscal institutions, especially when compared to the southern European periphery and the Latin American countries which make up most of the observations in the middle ground. In the nineteenth century, casual inspection

\footnotetext{
${ }^{18}$ For debt crises we present the "alternative debt crises" series which takes the numerator to be the number of years in which there was no resolution or international agreement on debt repayment rather than just the first year of a crisis.
} 
of the data suggests that at higher per capita income levels original sin is less likely to cause debt or banking crises. ${ }^{19}$ The next section controls for a host of other plausible factors that might be omitted from this simple scatter plot and illustrates the interaction between different types of crises.

\section{Statistical Findings}

Our statistical approach is a basic multivariate summary of the data. We correlate crisis probabilities with a set of key explanatory variables. ${ }^{20}$ We use pooled probit specifications, and the dependent variable is the first year of a debt crisis, currency crisis, banking crisis or twin crisis. Our data set is an unbalanced panel, and the observational unit is the country year. We omit country years that include ongoing crises. Throughout, we control for the lack of statistical independence between country observations by using heteroscedasticity robust, country clustered standard errors. ${ }^{21} \mathrm{We}$ first present specifications with as many variables as is feasible and then as a robustness check we drop the most statistically insignificant variables or we attempt to avoid possible collinearity problems. ${ }^{22}$ Finally after using pooled probits we move to linear probability models with country fixed effects to control for previously time invariant unobservable variables that could be causing spurious inferences in the pooled models.

\footnotetext{
${ }^{19}$ The case of Argentina in the late nineteenth century is perplexing in this regard. It was one of the richest countries in this period and yet the Baring crisis resulted in a major financial and economic blow to the republic. Our inference that higher per capita income alleviated the danger of original sin can only be made after disregarding Argentina.

${ }^{20}$ Endogeneity of the regressors as well as usual specification problems may be present. We attempted to mitigate endogeneity biases in un-reported specifications by using lagged values of the explanatory variables. Results in these cases did not change drastically in qualitative terms. Of course this solution is only valid if variables are not too persistent. Also, using lags creates measurement error issues which are likely to be problematic for consistent estimation.

${ }^{21}$ We estimated random effects probit models as well but found them to perform weakly as they are known to do when the number of explanatory variables is large relative to the sample size. The estimated correlation between within country observations was poorly estimated especially in the nineteenth century sample. Such specifications are more robust in the later sample and present results qualitatively very similar to the pooled probits we present. Finally "fixed effects" logit or conditional logit is a non-starter since many countries do not experience crises in the sample. We have however estimated linear probability fixed effects models to check the sensitivity of our some baseline models, and we present thee below.

${ }^{22}$ The appendix lists the key variables and their availability for each country so the reader can see what the various samples look like. The issue of model specification is of course not trivial. We are taking a decidedly reduced form approach, and we use the econometrics as supplements to the qualitative theoretical conclusions and historical record.
} 
For the most part our finding is that more original sin, when not properly managed, increases the likelihood of currency banking and debt crises. There is some evidence that currency mismatches catalyze debt crises by being at the root of banking and currency crises which then feed through to debt problems. However, in avoiding debt crises or financial meltdowns there is an important role for the level of financial and economic development and other hard to measure factors.

For example the positive association between original sin or hard currency debt on debt crises in both periods and banking crises in the twentieth century is smaller at the highest levels of per capita income. Without allowing for an interaction between original sin and this key variable, there is a positive and then a negative relationship between the ratio of hard currency debt to total debt and the frequency of debt and banking crises in the nineteenth century. All of this suggests that original sin may contribute to more financial crises but that sometimes the damage can be limited as the development process continues.

Our findings point to fairly solid evidence that mismatches are positively correlated with many types of crises especially in our post-1972 sample. This suggests that countries can mitigate the dangers of original sin. We also demonstrate that after controlling for country fixed effects, mismatches seem to be linked to banking and currency crises in both time periods. Moreover, we also find these types of events increase the chances of a debt crisis. Thus mis-managed original sin appears to have an important link to financial blowouts.

As mentioned, we also explore the inter-relation between various types of crises. We find strong evidence that debt crises are associated with the outbreak of a currency crisis in both periods. To some extent, the evidence shows that debt crises are associated with banking crises. An interesting difference between the two periods arises for twin banking and currency crises. In the nineteenth century, we find that banking crises and currency crises are positively associated (proxied by contemporaneous and lagged indicators of each type of crisis) though none of the coefficients is statistically distinguishable from zero at high levels of confidence. In the twentieth century, however, we see a negative relationship between the two types of crises. This evidence presents the possibility that conditional on having a crisis, episodes of instability were more likely to overwhelm the financial system in the nineteenth century, whereas today, banking crises are quite unrelated to currency crashes and debt sustainability. 


\subsection{Debt Crises}

Tables 1 and 2 present results from various specifications where the initial year of a debt crisis is the dependent variable. Table 1 is for the 1880 to 1913 sample and Table 2 is for the 1972-1997 sample.

Column one of Table 1 presents a comprehensive specification that includes a variable set as large as possible and which also allows for controls for original sin and currency mismatches. We see that there is an inverse $\mathrm{U}$ shaped pattern in original sin and in mismatches. ${ }^{23}$ There is also evidence of debt intolerance. These variables are statistically significant (at better than the 90 percent level of confidence) at the means for each of these controls. ${ }^{24}$ Figure 10 illustrates the shape of the marginal effect for various values of the hard currency debt ratio with two standard error confidence bands.

The size of the estimated coefficients on the hard currency debt ratios are also economically significant. Figure 11 presents the predicted probabilities of a debt crisis for various values of the ratio of hard currency debt to total debt. We hold all controls at their mean except the currency crisis indicator and the lagged banking crisis indicator which take on the value one or zero. By allowing the other crisis indicators to vary, we demonstrate the strength of the interaction between various types of crises. Here one can easily see the significance of this measure of original sin especially in the range of original sin equal to 50 percent where the predicted probability of having a debt crisis peaks. One also can appreciate the interaction between banking crises, currency crises and debt crises. At an original sin level of 50 percent, having a banking crisis in the previous year and a currency crisis in the same

\footnotetext{
${ }^{23}$ The reason we include squared terms is twofold: first, the scatter plots suggest there might be such a relationship; second, including a simple linear term return a coefficient on original sin that is negative and statistically insignificant. The latter result contradicts the basic theoretical proposition in the literature and may also arise due to omitted variables biases which we discuss below. The squared term allows us to readily illustrate these two possibilities simultaneously

${ }^{24}$ The statistical significance of the interaction effects and polynomial terms must be approached with caution. We are interested in the statistical significance of the partial derivative of the probability with respect to say hard currency debt at various values. We do not report the statistical significance of such an effect for the debt intolerance interactions or for the interactions of variables with GDP. We do however present simulated confidence bands and the mean partial effect of original sin arising from the quadratic in original sin in figures below. These were calculated using code made available by William Clark at http://homepages.nyu.edu/\% 7emrg217/interaction.html.
} 
year increases the predicted probability of a debt crisis by over 10 times from 0.023 to 0.25. Column 2 pares down the specification dropping the controls for mismatch to see if multicollinearity is a problem. We still see a similar quadratic form. Column 3 leaves out original sin and leaves in the mismatch variables. Mismatch itself does not appear to be a strongly statistically significant direct determinant of debt crises in the nineteenth century. ${ }^{25}$

The inverse $\mathrm{U}$ in original sin says that more original sin is associated with a higher likelihood of a debt crisis, but those observations with levels of original sin greater than 50 to 60 percent face a lower likelihood of a crisis despite higher levels of exposure to hard currency debt. These are the countries in the areas of recent settlement like Canada, Australia, New Zealand, and the US which had strong financial systems, good fiscal institutions and which borrowed largely for productive investments. The possibility of three econometric inference problems arise here: extreme heterogeneity related to time-invariant characteristics, omitted and unobservable time-varying characteristics correlated with our explanatory variables and omitted variables correlated with the included variables that are potentially observable. We deal with omitted but time invariant factors below, and we see that the evidence is unclear as to whether these factors are at play. In any case, the inverse $U$ relationship suggests a division of the countries in the nineteenth century sample into three groups. The first group includes the financial centers of Europe with low or no original sin and few crises. The second and third groups consist of emerging market countries. Countries in the second group possessed stable institutions, strong and flexible financial systems able to cope with crises (e.g., the US or Japan, Denmark and Sweden) or intricate correspondent banking relationships and colonial ties (e.g., Australia, Canada, and New Zealand). The third group includes the periphery countries of the Latin American cone and the Mediterranean region with episodes of fiscal profligacy (Greece and Portugal) or periods of instability in their banking systems (e.g., Argentina with its new banking laws of the 1880s and Italy prior to the financial sector restructuring that took place in the $1890 \mathrm{~s}){ }^{26}$

In terms of mismatch, there is evidence that past the mean level of mismatch a worse mismatch position leads to a lower likelihood of a debt crisis. While the partial

\footnotetext{
${ }^{25}$ This is true even if we exclude the squared mismatch term.

${ }^{26}$ See the capsule histories of these crisis episodes included in Bordo et. al. (2001) for a brief summary and further reading. Bordo and Meissner (forthcoming) also report in more detail the experiences of the US, Australia, Brazil and Argentina in the 1890s.
} 
effects are not highly statistically significant, the point estimates do suggest that on the way up to the mean mismatch reserve holdings or greater export exposure can limit the chances of a debt crisis. After the mean, the marginal effect is estimated to be negative. This could be further substantiation (albeit weak due to the lack of precision in the estimates) of the idea that other factors that we have not controlled for such as the ability to deal with and manage crises matter. For example, amongst the countries with very high mismatch levels we see Portugal, Italy and Greece but also the US, Australia, and Canada.

Most other variables have signs that fit our priors: more gold reserves relative to notes outstanding, a larger trade surplus to GDP ratio, not being on the gold standard, a lower long-term interest rate, and a calm international environment in capital markets, as measured by the interest rate on British consols, are all associated with lower probabilities of debt crises. The statistical significance of the coefficients on these variables varies however. ${ }^{27}$ There is also evidence as we have seen, that currency crises and banking crises are positively associated with the outbreak of a debt default. This gives currency to the balance sheet view of crises discussed above.

We also provide a measure of the fit of the model. This is gauged by the percentage of actual crises that were predicted to be crisis episodes, and the percentage of non-crisis years that are predicted to be non-crisis years. We use a predicted probability of greater than 0.1 to classify a country as having a debt crisis. This is a low threshold, but debt crises are relatively rare in the raw sample. (The sample frequency is 0.01.) For the debt crises, the type I errors are fairly small and the type II errors are mainly concentrated in the country years immediately preceding or coming after actual crises. ${ }^{28}$

Table 2 presents the results of similar specifications for debt crises for the 1972-1997 period. Column 1 shows that there is a positive relationship between our measure of original sin and debt crises. The estimate is not too precise just as one

\footnotetext{
${ }^{27}$ Unreported likelihood ratio tests between the shorter and longer models cannot reject their equivalence. Perhaps the positive coefficient on the gold standard variable is compatible with theories that argue that rigid exchange rate policies amplify negative external shocks more than flexible rates. But since the statistical significance varies a lot by specification, we do not see overwhelming evidence for any hypothesis suggesting a positive or negative coefficient here. See Edwards (2003) for a wideranging discussion of exchange rate regimes and crises.

${ }^{28}$ For other types of crises we fail to correctly classify many crisis episodes even at low thresholds. We use the 0.1 barrier for currency and banking crises. Obviously our tabulations are sensitive to these thresholds. Our maximum predicted probabilities rarely exceed 0.2 for any type of crisis.
} 
might expect after having looked at the scatter plots. The experience at high levels of original sin appears to be quite varied even after conditioning on a host of controls.

In column 1 there is no sign of mismatch being a statistically significant determinant of debt crises and no evidence of debt intolerance. Similar to the nineteenth century, we do see a positive and statistically significant association between currency crises and debt crises. Having a currency crisis raises the probability of having a debt crisis by over 5 percentage points. The point estimates on contemporary and lagged values of banking crises are positive but not highly statistically significant.

To take the strain off the sample with so many explanatory variables, we pare down the specification in column 2 and find that original sin has a positive impact on the likelihood of a crisis, and it is now slightly more statistically significant. Column 4eliminates the original sin measure and reinstates the mismatch measure to see if collinearity might have been the reason for the low precision in column 1 . Indeed in column four we see that mismatches increase the susceptibility to debt crises and the marginal effect is statistically significant. A one point increase in the mismatch ratio (equivalent to one standard deviation) would imply that the probability of a debt crisis increases by 0.02 .

Column 3 introduces the logarithm of GDP per capita and its square as a control variable. ${ }^{29}$ This allows us to show how GDP per capita interacts with original sin to affect crisis outcomes. When we do this we see that middle income countries, roughly where the emerging markets would be located, are the most likely to have a crisis when other control variables are held constant. Figure 12 shows this by presenting the predicted probability of a crisis for various levels of per capita output holding original sin at 100 (its maximum and also the modal value). We also compare those probabilities when the currency crisis indicator is one and zero so as to show yet again that at any level of output per capita currency crises and debt crises are likely to come together when original sin is high. It should be noted that the hump shaped pattern does not disappear when we include the mismatch position along with the

\footnotetext{
${ }^{29}$ We tried simply interacting original sin with GDP per capita as we did for the 1880-1913 period but the results seemed counterintuitive although we cannot rule out such a specification for any other reason. We found the marginal effect of original sin was negative and approached zero for higher levels of GDP per capita. On the other hand the marginal effect of GDP per capita was negative and approached zero as original sin increased. We also interacted original sin directly with GDP per capita and its square. The marginal effects were consistent with the idea that original sin's marginal impact is largest at intermediate levels of per capita GDP.
} 
original sin measure or even by itself. In fact mismatch enters with a negative sign and is highly statistically insignificant in either specification.

The quadratic hump we see in the predicted probabilities leads us to suggest that countries can be broken into three categories when original sin is high. First, to the left, are the poorest countries (e.g., Colombia, Nigeria, and Pakistan) which, despite suffering from original sin, are not relying on external finance as much as the countries in the "big push" phase of development (e.g., Argentina, Brazil, Korea, Mexico, and Taiwan). Then, to the far right, there are the highly developed countries (e.g., Belgium, Canada, Denmark, Norway, Spain, and Sweden) which because they are small, or unlucky not to have a key currency, also suffer from liability dollarization. Nevertheless, either external financing is less significant or they have the capability to deal with shocks to the financial system in ways we have not controlled for and hence to avoid crises. The middle income emerging markets which rely on external financing are the ones most at risk of seeing their hard currency liabilities interact with currency crashes leading to a debt default episode.

Figure 13 illustrates this four part categorization. Here the "radar" graph plots variables of interest on each axis and the lines connecting the particular values represent the ordering of the different groups of countries. We classified countries into four groups based on GDP per capita and levels of original sin. The first are those with GDP per capita lower than $\$ 2,900$ where the average level of original sin between 1993 and 1997 was 99.9 percent. The second are those with GDP per capita between $\$ 2,900$ and $\$ 8,100$ with an average value of average original sin equal to 76 , and finally two groups with GDP above $\$ 8,100$ one with an original sin level greater than 20 percent and also one with less than 20 percent.

Next we chose variables of interest such as the average trade deficit within each group, the average time spent in a debt crisis, the average predicted probability of a debt crisis (based on the model in column three of table 2) and the median predicted probability based on the same model and our mismatch variable. The richest countries are lower on all five dimensions. The middle income, emerging markets are highest on these dimensions except for the average predicted probability of having a debt crisis. ${ }^{30}$ Trade deficits are twice as high on average in these countries and they

\footnotetext{
${ }^{30}$ This measure is sensitive to the GDP cutoff point. If we lower it slightly then we include a few more countries like Chile and Venezuela which had debt crises. This reverses the ordering on this dimension. In any case the difference is not significant..
} 
have a median predicted probability twice as high as the less developed countries. . There are quite a few observations of rich countries with original sin higher than 20 percent (or 50 percent for that matter). So while one might be tempted to argue that only rich countries were free from original sin and hence have lower probabilities of a crisis these numbers refute such an argument. It would appear that many of the richest countries have original sin and still have a low chance of a debt crisis. Moreover the figure suggests such countries run bigger trade surpluses or lower deficits and also control their mismatch positions better than the middle income countries making them even less prone to crisis episodes. Nevertheless it would be wrong to assume that this is all of the story as the probit results which hold other factors constant show. Figure 12 illustrates that even after controlling for these factors middle income countries seem to be more at risk.

\subsection{Currency Crises}

Column 1 of Table 3 presents an inclusive specification where the dependent variable is the probability of having a currency crisis between 1880 and $1913 .{ }^{31}$ There are 17 events to be predicted in this sample. None of the variables are statistically significant at standard levels of confidence except for the gold cover ratio. Endogeneity is a worry here since quite obviously it would be much lower in the midst of an attack on a currency.

In terms of marginal effects, we see still see a quadratic in original sin in column 2, and a positive relationship between the mismatch variable in column three. Some marginal effects of the other variables have the expected signs while others do not. However, nothing in column two or three is statistically significant except for the trade balance to GDP which has a positive sign as it did in the Frankel and Rose

\footnotetext{
31 As Flandreau and Zúmer (2004) have emphasized, the debt revenue ratio and the original sin variables can increase when the nominal exchange rate changes and when there is hard currency debt. To the extent that this supports the argument that a crisis is more likely with a depreciation, then there is no problem here. But an endogeneity problem could arise if we predict currency crises with variables that are functions of the nominal exchange rate such as the hard currency debt ratio. To avoid this issue we tried lagging such variables in the currency crisis specifications. Our results regarding such variables in the currency crisis regressions are similar in qualitative terms when we use one or two lags of mismatch, hard currency to total debt and the debt to revenue ratio.
} 
(1996) study of the late twentieth century. ${ }^{32}$ Lagging this variable causes the magnitude of the coefficient and its statistical significance to fall also suggesting some endogeneity problems.

The positive coefficient on the mismatch variable suggests that original $\sin$ is dangerous, but that countries that have original sin may be able to avoid currency crises if they manage to collect adequate reserves or are sufficiently open. Since the outbreak of a debt crisis seems to be associated with currency crises (see Table 1), this is weak evidence that poorly managed original $\sin$ is indirectly associated with currency crises.

In Table 4 we present similar specifications that try to explain currency crises between 1972 and 1997. Here there is evidence that original sin leads to a higher chance of a currency crisis when we do not control for the mismatch position. Mismatches however do seem to be strongly associated with currency crises both controlling for original sin (column one) and not controlling for original sin (column 3). This result is again highly suggestive that proper management of original sin can help alleviate not only currency crises but the chain reactions leading to debt default related to balance sheet effects.

The current account is negatively related to currency crises (as is intuitive). Increases in long-term interest rates lead to more crises as do rapid increases in the money supply. These marginal effects are all statistically significant throughout. There is some evidence that a banking crisis in the previous year is associated with a currency crisis (p-value 0.16).

Overall the models in the nineteenth century fit poorly as judged by the high Type I errors while the models of the twentieth century make far fewer of such errors. The opposite is true of type II errors. In the latter sample, far too many currency crises are predicted. In terms of comparison, it seems as if the most we can say is that mismatches contribute to currency crises in both periods. At the same time this comparison is strained because of the high degree of uncertainty surrounding the point estimates of the marginal effects.

\footnotetext{
${ }^{32}$ Alas, the marginal effect of changes in the current account in their paper was statistically insignificant. The seemingly counter-intuitive result that net exporters have a higher chance of a crisis seems to arise from the fact that the small peripheral countries in our sample tend to be net exporters while GB, France and Switzerland, for example, have highly negative ratios for this variable and had of course
} 


\subsection{Banking Crises}

In pooled probit specifications there is no overwhelming evidence that banking crises are associated with original sin and currency mismatches in either period. However, the evidence is again mixed in terms of statistical significance. Similar to what we see with debt crises, there appear to be factors that diminish the impact of original sin. Between 1880 and 1913 we see a quadratic or inverse $U$ as we did in Table 1. Between 1972 and 1997 we see that the impact of more original sin is higher in low and middle income countries than in high income countries. There is evidence of a straightforward positive link between mismatch and banking crises in the twentieth century.

Column one of Table 5 presents a baseline probit model for banking crises. Here we see the same inverse $U$ pattern for original sin that we saw with debt crises. However we cannot reject the hypothesis that the entire marginal effect is zero at standard levels of confidence.

Columns 2 and 3 of Table 5 re-run the basic specification of column 1 to see if collinearity between original sin and mismatch contributed to the lack of precision. It turns out that in neither column are the coefficients much different and their statistical significance does not change dramatically. ${ }^{33}$ In terms of fit, all of the models seem nearly equivalent by the log likelihood values. Only about 20 percent of actual sample crises are predicted reliably. Most of the other controls have the expected signs but are not statistically significant except the trade surplus to GDP ratio. We do see positive marginal effects on the currency crisis indicators but neither of them are statistically significant at conventional levels.

Table 6 turns to the late twentieth century. In column one we see results similar to the debt crisis specifications in Table 2. Original sin and mismatch are positively related to crises but alas they are both statistically indistinguishable from zero. Column two demonstrates that original sin is not statistically insignificant because of severe collinearity with the mismatch control. Columns three and four are more promising in terms of substantive lessons. In column three we tried to see if an

\footnotetext{
${ }^{33}$ One possibility why mismatch is not significant here, while it seems to be in the twentieth century, is that the measure here relates only to public debt and borrowing. In the twentieth century sample the measure includes both public and private borrowing. As we shall see, controlling for such heterogeneity shows mismatch is positively correlated to banking crises in the nineteenth century.
} 
interaction between the logarithm of GDP per capita and original sin made the estimates more precise. Figure 14 illustrates that at higher levels of GDP per person a 100 percent level of original sin is less dangerous. The predicted probability drops by more than one third when moving from an income level of slightly less than $\$ 3,000$ (e.g. Mexico, Malaysia, Thailand, Brazil in 1995) to an income level matching Austria, Canada, Denmark, or the US of roughly $\$ 22,000 .{ }^{34}$ Finally column four shows that the marginal effect of a greater mismatch is positive and statistically significant. A one point increase in the mismatch variable would lead to a substantive increase in the predicted probability of roughly 0.02 percentage points. The other controls that are statistically significant are the growth of the money supply (positive coefficient), the trade surplus to GDP ratio (negative) and the long-term interest rate (positive). We find negative point estimates for the marginal effects of currency crises and lagged currency crises but these are not close to being statistically significant. Overall the results again suggest that avoiding mismatches and other unobservables that may be highly correlated with GDP per capita in some way affect how dangerous original $\sin$ is. We also find no evidence that currency crises cause or are associated with banking crises in this late twentieth century sample. This final bit of evidence suggests to us that there is a big difference between banking crises in the nineteenth century and the twentieth century. Specifically banking crises seem to be isolated events in the most recent period, and we conjecture they have their roots in regulation, deregulation and domestic liberalization. In the previous period banking was less regulated, more open, less protected by a lender of last resort, and there is some very weak evidence of a more direct connection between currency and banking distress.

\subsection{Robustness: Controlling for Country-Level Heterogeneity}

In our nineteenth century sample we found some evidence that after a certain point more hard currency debt relative to the total seemed to be associated with fewer debt crises and banking crises. In the late twentieth century, we also see some evidence that original sin interacts in a complex way with GDP per capita. Above we noted that this finding could be due to unobservables or omitted observables.

\footnotetext{
${ }^{34}$ These figures are measured in real 1989 US dollars.
} 
One robustness check is to make sure that these findings are not spurious or due to the possibility that the level of original $\sin$ is correlated with factors or characteristics of countries we have left out of the analysis. Perhaps those most at risk take care to protect their financial systems from crises or have effective ways of dealing with crises despite their high levels of original sin. If these factors were time invariant, an econometric solution to such a problem is to include country-level indicator variables or "fixed effects".

Since this is infeasible to do in a limited dependent variable model with our particular data configuration, we move to a "fixed effects" linear probability model estimated by OLS. Table 7 re-specifies the models of column 1 from Table 1, column 1 of Table 3 and column 1 of Table 5 in this way. Like the previous results, the models fit fairly poorly since there are so few crises compared to non-crisis years. Many of the coefficients on the basic macro controls are statistically insignificant. Nevertheless the results regarding the coefficients on the original sin and mismatch variables are qualitatively very similar to the findings in the previous tables.

For debt crises and banking crises, we find evidence of the very same quadratic pattern from Table 1 and Table 5. However the marginal effect of the hard currency debt ratio is not statistically significant. ${ }^{35}$ We take away three lessons from column 1 and column 3. The fact that the quadratic shape (i.e., the point estimates on original sin and its square are positive and negative respectively) does not disappear suggests that it is unlikely to be time invariant unobservables which are causing the inverse U. If it were simply a case of omitted time invariant variables we would have expected the inclusion of fixed effects to reveal a statistically significant and positive relationship between original sin and crises. At the same time, there are two other possible interpretations of column one and column three. One is that since original sin moves relatively slowly over time the fixed effects would naturally be unable to estimate the impact of original sin on crises. But equally one might also conclude that hard currency debt is not associated with debt or banking crises once proper controls are included, and we cannot rule this out. Only more clever identification strategies or more data will be able confirm which one of these assertions is correct.

\footnotetext{
${ }^{35}$ That is, the true marginal effect of changes in the hard currency debt ratio (at all values of the hard currency debt ratio) calculated with the analytical standard error of the marginal effect and not the coefficient on the square term. Again, we used the code supplied by William Clark to calculate these figures.
} 
If one still argued for the inverse $U$ on the grounds that fixed effects are inefficient and an inappropriate specification, then for the nineteenth century we are left with the result that time-invariant underlying fundamentals like empire status or resource endowments probably do not explain how places like the US, Canada, Australia and Scandinavia managed to carry high original sin and also avoid severe financial crises. There is also no evidence that a better mismatch position directly helped avoid debt crises. This suggests the possibility that these places had a more active approach to managing crises or their financial systems were structured in a way that helped stave off financial meltdown following a major shock. ${ }^{36}$ Oppositely there is little evidence that places like Argentina, Brazil, Greece, Italy, and Portugal faced financial meltdowns because of time-invariant characteristics such as "bad government" or institutions or simply because they were in the geographic or economic periphery. ${ }^{37}$ Moreover we can observe that financial systems and institutions change significantly over time within countries. The run up to the Portuguese debt debacle in 1892 witnessed fiscal excess or the Argentinean financial system of the 1880s was poorly designed. But in the wake of these crises structural reforms may have been made that secured a more sustainable financial position in later decades. To eliminate the quadratic and have the hope of revealing a positive marginal effect of hard currency debt we would need better controls and indicators for

\footnotetext{
${ }^{36}$ The endogeneity of the level of original sin should be explored and other experiences across time should be compared. The endogeneity bias would appear to be small. Eichengreen, Hausmann and Panizza (2003, 2005), and Flandreau and Sussman (2005) take the view that original sin is inversely related to country size. Having a financial center also decreases original sin. Being large and/or having a financial center makes for liquid markets in the domestic currency and increases the demand for such assets in the portfolio of international investors. Because of this, "endogeneity" may be less of an issue than one might conjecture at the outset. Evidence from Australia, New Zealand and the US in Bordo, Meissner and Redish (2005) suggests that wars and large shocks that closed international markets and forced governments into the domestic markets catalyzed the process. Still other factors are obviously necessary for these factors to be viable explanations.

${ }^{37}$ In other un-reported specifications, we tried using proxies for good institutions and financial development in our probit models. We included the ratio of the money stock to GDP, a British Empire indicator, a central bank indicator and a branch banking indicator. None of these variables eliminated the quadratic pattern or gave rise to a conditionally positive relationship between original sin and debt crises, currency crises or banking crises. In the debt crisis specifications, it is not feasible to estimate the equations with an empire dummy simply because no included dominion, colony or other member of the British Commonwealth ever had a debt default in this period. This indicator would be a perfect predictor of not having a debt crisis. So we are left clinging to the notion that the countries with lots of original sin like the US Canada, Australia and New Zealand and perhaps the Scandinavian countries were different along other dimensions than those captured by these proxy variables. Caballero, Cowan and Kearns (2004) talk about currency-trust and country-trust which could be factors at play here but which are not easily captured with any one explanatory variable.
} 
the robustness of the financial system and so forth. More research is clearly required here.

For currency crises, the link between a crisis and original sin (or mismatch) is indirect since the coefficients on hard currency debt are not highly statistically significant. Rather it turns out that the association between original sin and currency crises seems to be coming through the outbreak of banking problems in the previous year. Indeed mismatches seem to be positively associated with banking crises as seen in column 3 even after controlling for unobservables in this way. The coefficient is highly statistically significant as well. In column 2 there is evidence that banking crises do have an impact on currency crises which in turn have a positive impact on debt crises as seen in column 1. This suggests that good debt management and sound borrowing practices were at the root of preventing financial meltdown.

We also performed a fixed effects linear probability model for the 1972-1997 period and report these results in Table 8. Given the way we have chosen to control for original sin by using the 1993-1997 average we are unable to control for this key variable. The key determinants of debt crises seem to be the debt output ratio, interest rates and also the existence of a currency crisis. Most of the other coefficients are not statistically significant.

Importantly we also find that mismatch is positively and statistically significantly related to currency crises ( $\mathrm{p}$-value 0.026), and for banking crises the coefficient is also positive but only has a p-value of 0.19 . We note a similar indirect connection to debt crises as in the nineteenth century. The chain of logic points to the following conclusion. Better borrowing safeguards in the form of lower mismatches could stem the explosion of a currency crisis. Since contemporary and lagged currency crises appear to be strongly associated with debt crises in column 1 of Table 8, all else equal, it is likely that better mismatches can limit exposure to financial implosion.

The evidence from controlling for unobservables and country-specific heterogeneity provides very mixed evidence (at best) for the idea that original sin itself is the culprit for major financial meltdowns. On the other hand mismatch matters. Lower mismatches seem to be associated in both periods with fewer outbreaks of currency or banking crises. Stemming these types of crises assists countries in avoiding the onset of a debt default or a total financial meltdown. The presence of original sin makes implementing safeguards important. Reserve 
accumulation or openness to exports are viable strategies to avoid trouble currency and banking runs which in turn have a high likelihood themselves of feeding through to debt crises.

\section{Conclusions}

Our central finding is that hard currency debt itself may not always generate a higher likelihood of a financial crisis. Some countries in the nineteenth century with very high levels of original sin were less prone to debt crises than those with intermediate levels. In the late twentieth century, many countries have original sin levels of 100 percent and have avoided crises. On the other hand, emerging markets that also suffer from original sin fell victim to debt crises and had high financial instability.

We find evidence that not backing up hard currency debt with foreign reserves and having a larger export sector for a given level of hard currency debt can both help decrease the incidence of debt, currency and banking crises. Mismatches matter. We have found evidence both before 1913 and since 1972 that they matter for banking and currency crises. Moreover, since there is evidence that outbreaks of banking and currency crises are associated with debt crises, mismatches are associated at a fundamental level with more robust financial systems. The evidence is then that original sin matters when not properly managed. Reserve accumulation, openness to international trade and exchange rate policy are all important. Nevertheless our mismatch measure is far from ideal, and it is somewhat collinear with the original sin measure. More and better data is the only solution to this identification problem. Nevertheless Eichengreen, Hausmann and Panizza (2003) argue that original sin is a second best outcome. If countries cannot issue own-currency debt and then are forced by market discipline to hold costly reserves to insure themselves against currency speculation this may not be socially optimal.

The interaction effects we tested for lead us to suggest a division of various types of countries. Three or four categories seem to be apparent. The financial centers with low original sin and strong financial fundamentals obviously avoid crises. Other highly developed countries that are small in terms of global output, and carry high 
original sin also avoid severe financial crises. In terms of less developed countries, there are many which are relatively closed to external capital flows or have yet to kick start the development process. These countries also have original sin like the rest of the world but are not prone to volatile capital movements. The most dangerous combination seems to be high original sin in an emerging market. These countries saw huge capital inflows in the 1880s, the late 1970s and early 1980s and again in the early 1990s. Their fragility to current account reversals and the virulence of these two major episodes is no doubt explained in part by exposure to hard currency liabilities.

There is also a bigger picture in terms of the interaction between crises. We find evidence of connections between banking, currency and debt crises. The balance sheet view of crises or the third generation type of crisis is as much of a fact of life today as it was in the late nineteenth century. Given that third generation crises remain a possibility, the evidence suggests that better balance sheet management will be necessary to help avoid crises. It will also keep financial turbulence from becoming a financial catastrophe.

Finally we end on a cautious note. Our results are fragile to the exact specification we impose and the sample sizes are precariously small. The econometric techniques and specifications could be further refined as a means to improve efficiency. The models we estimate are not direct estimates of structural equations. The original sin data is incomplete and more and better measures will have to be collected. We need more comprehensive measures that include domestic original sin and private finance. We also need longer time series of the original sin measure than those currently available. Once this data has been collected and analysed, our tentative assertions will face more stringent tests. We offer early conclusions, but to improve our understanding of the connection between hard currency debt and financial chaos better data availability is of the utmost importance.

Again, our bottom line is that original sin often makes debt crises more likely and makes avoiding currency and banking crises more difficult. But the lesson from two different periods of globalization is that more careful debt management policies and the development of sound fiscal and financial institutions seem to make it possible for governments and firms to avoid severe financial crises and economic disaster. 


\section{References}

Beim, David O. \& Calomiris, C.W. (2001) Emerging Financial Markets New York: MacGraw-Hill, 2001.

Berg, Andrew and Catherine Patillo (1999) "Are Currency Crises Predictable? A Test. IMF Staff papers, vol. 46, no. 2 June.

Bordo, Michael D. (2003) "Market Discipline and Financial Crises Policy; An Historical Perspective.” Research in Financial Services: Private and Public Policy. vol 15, pp154-182.

Bordo, Michael D., Barry Eichengreen, Daniela Klingebiel, and Maria Soledad Martinez-Peria (2001) "Is the Crisis Problem Growing More Severe?" Economic Policy vol. 32 pp 51-75.

Bordo, Michael D. and Marc Flandreau (2003) "Core Periphery, Exchange Rate Regimes and Globalization" in Michael D. Bordo, Alan M. Taylor and Jeffrey G. Williamson eds. Globalization in Historical Perspective. Chicago: University of Chicago Press.

Bordo, Michael D., and Jonung, L. (1996). 'Monetary regimes, inflation, and monetary reform: An essay in honor of Axel Leijonhufvud.' in Inflation, Institutions, and Information: Essays in Honor of Axel Leijonhufvud (D. Vaz and K. Velupillai, eds.). London: Macmillan.

Bordo, Michael D. and Christopher M. Meissner (forthcoming) "Financial Crises, 1880-1913: The Role of Foreign Currency Debt" with Michael D. Bordo in Sebastian Edwards, Gerardo Esquivel and Graciela Marquez, et. al. eds. (provisional title Growth, Protection and Crises: Latin America from an Historical Perspective) Cambridge: National Bureau of Economic Research.

Bordo, Michael D., Christopher M. Meissner and Angela Redish (2005) "How 'Original Sin' was overcome: the evolution of external debt denominated in domestic currencies in the United States and the British Dominions 1800-2000.” in Barry Eichengreen and Ricardo Hausmann (eds.), Other People's Money Chicago: University of Chicago Press

Bordo, Michael D. and Anna Schwartz (1996) "The Operation of the Specie standardEvidence for Core and Peripheral Countries" in de Macedo, Jorge, Eichengreen, B and Reis, J (eds.) Currency Convertibility: The Gold Standard and Beyond, Routledge, London.

Caballero, Ricardo, Cowan Kevin and Jonathan Kearns (2004) "Fear of Sudden Stops: Lessons from Australia and Chile" NBER working paper 10519.

Céspedes, Luis Felipe, Roberto Chang and Andrés Velasco (2004) "Balance Sheets and Exchange Rate Policy" American Economic Review vol.94 (4) September. 
Edwards, Sebastian (2003) "Exchange Rate Regimes, Capital Flows and Crisis Prevention" in Martin Feldstein ed. Economic and Financial Crises in Emerging Markets. Chicago: University of Chicago Press.

Eichengreen, Barry and Ricardo Hausmann (1999), "Exchange Rates and Financial Fragility" Federal Reserve Bank of Kansas City. New Challenges for Monetary Policy pp. 329-368.

Eichengreen, Barry, Ricardo Hausmann and Ugo Panizza (2003) "Currency Mismatches, Debt Intolerance, and Original Sin: Why they are not the Same and Why it Matters." NBER working paper 10036.

Eichengreen, Barry, Ricardo Hausmann and Ugo Panizza (2005), "The Pain of Original Sin," in Barry Eichengreen and Ricardo Hausmann (eds.), Other People's Money Chicago: University of Chicago Press

Flandreau, Marc (2003) "Crises and punishment: moral hazard and the pre-1914 international financial architecture" in Marc Flandreau ed. Money Doctors: The Experience of International Financial Advising, 1850-2000. London: Routledge.

Flandreau, Marc and Nathan Sussman (2005), "Old Sins," in Barry Eichengreen and Ricardo Hausmann (eds.), Other People's Money, Chicago: University of Chicago Press.

Flandreau, Marc and F. Zúmer (2004) The Making of Global Finance. OECD: Paris. Data from http://www.eh.net/databases/finance/

Frankel, Jeff and Andrew K. Rose (1996) "Currency Crashes in Emerging Markets: An Empirical Treatment" (with Jeffrey Frankel), The Journal of International Economics.

Glick, Rueven and Michael Hutchinson (2001) "Banking and Currency Crises: How Common are Twins?" in Financial Crises in Emrging Markets R. Glick, R. Moreno and M.M. Spiegel eds. Cambridge University Press: New York.

Goldstein, Morris and Philip Turner (2004), "Controlling Currency Mismatches in Emerging Market Economies” Washington: Institute of International Economics.

Meissner, Christopher M. (forthcoming) "New World Order: Explaining the International Diffusion of the Gold Standard, 1870-1913" Journal of International Economics.

Mishkin, Frederic S. (2003) "Financial Policies and the Prevention of Financial Crises in Emerging Market Countries" in Martin Feldstein ed. Economic and Financial Crises in Emerging Markets. Chicago: University of Chicago Press. 
Obstfeld, Maurice and Alan M. Taylor (2003) "Sovereign Risk,Credibility and the Gold Standard, 1870-1913 versus 1925-1931” Economic Journal vol. 113 (487) pp 135

Reinhart, Carmen, Kenneth Rogoff and Miguel Savastano (2003), "Debt Intolerance," Brookings Papers on Economic Activity 1, pp.1-74.

\section{Data Appendix}

\section{General notes:}

For the 1972-1997 sample most of our macroeconomic variables come from Bordo et. al. (2001) and sources are described therein. Where a variable was missing we filled it in according to the descriptions below and in the text.

\section{Debt:}

1880-1913: In general we have defined external debt or hard currency debt as the amount outstanding of long-term debt issued abroad plus the amount outstanding of domestic gold (or silver) debt. Internal debt refers to the outstanding stock of domestic paper debt. However in a few cases listed below we have not been able to discern from the sources how much of the "domestic" or internal debt was payable in gold. More work will have to be put into these cases. However, one will note that for these cases the total amount of domestic debt is rather small.

1972-1997: Most data was available in the World Bank's Global Development Finance database. This includes many varieties of international obligations0 including private, official and multilateral debt. We supplemented this with external debt from the International Financial Statistics.

\section{Long-term interest rates:}

1880-1913 This is the interest rate on long-term bonds given by Obstfeld and Taylor (2003). 
Exchange rate regimes: Data on gold standard adherence comes from Meissner (forthcoming) augmented with data from Obstfeld and Taylor (2003)

\section{Default Indicator:}

1880-1913: Our default indicator was created if there were one or more defaults prior to 1880 .

1972-1997: Our default indicator was created if there were one or more defaults prior to 1972 .

This data is taken from a spreadsheet underlying Reinhart, Rogoff and Savastano (2003).

Crisis Dating: As in Bordo et. al ( 2001) we date currency and banking crises using both qualitative and quantitative evidence. For all countries besides Austria-Hungary, Russia, New Zealand, South Africa, Mexico, Turkey, Egypt, Uruguay and India we have relied on the dates of Bordo et. al. We have tried to date currency crises, when possible, by using an approach based on the exchange market pressure (EMP) methodology which looks at changes in reserves, the exchange rate and the interest rate.

Debt crisis dates were based on Beim and Calomiris (2001). Only private lending to sovereign nations is considered when building those default dates. Not every instance of technical default is included in the chronology, the authors identified periods (six months or more) where all or part of interest/principal payments were suspended, reduced or rescheduled. Some of those episodes are outright debt repudiations, while others were reschedulings agreed upon mutually by lenders and borrowers. Also data is taken from a spreadsheet underlying Reinhart, Rogoff and Savastano (2003). 
Table 1 Determinants of Debt Crises, 1880-1913

\begin{tabular}{|c|c|c|c|}
\hline Regressors & (1) & (2) & (3) \\
\hline $\begin{array}{l}\text { Hard currency debt as } \\
\text { a percentage of total debt }\end{array}$ & $\begin{array}{l}0.075^{\star \star} \\
(0.031)\end{array}$ & $\begin{array}{l}0.061^{* *} \\
(0.030)\end{array}$ & --- \\
\hline $\begin{array}{l}\text { Square of hard currency } \\
\text { debt ratio }\end{array}$ & $\begin{array}{c}-0.073^{* *} \\
(0.030)\end{array}$ & $\begin{array}{c}-0.069^{\star *} \\
(0.027)\end{array}$ & --- \\
\hline Debt/Revenue & $\begin{array}{l}-0.002^{*} \\
(0.001)\end{array}$ & $\begin{array}{l}-0.001 \\
(0.001)\end{array}$ & $\begin{array}{l}-0.001 \\
(0.002)\end{array}$ \\
\hline Debt/Revenue*Pre-1880 Default & $\begin{array}{c}0.009^{* * *} \\
(0.003)\end{array}$ & $\begin{array}{c}0.003 \\
(0.002)\end{array}$ & $\begin{array}{l}0.005^{\star} \\
(0.003)\end{array}$ \\
\hline Pre-1880 Default & $\begin{array}{c}-0.221^{* * *} \\
(0.018)\end{array}$ & $\begin{array}{l}-0.058 \\
(0.062)\end{array}$ & $\begin{array}{l}-0.129^{*} \\
(0.074)\end{array}$ \\
\hline Mismatch & $\begin{array}{c}0.003 \\
(0.003)\end{array}$ & --- & $\begin{array}{c}0.005 \\
(0.005)\end{array}$ \\
\hline Square of mismatch & $\begin{array}{l}-0.001 \\
(0.0004)\end{array}$ & --- & $\begin{array}{l}-0.001 \\
(0.001)\end{array}$ \\
\hline Trade balance/GDP & $\begin{array}{l}-0.054 \\
(0.044)\end{array}$ & $\begin{array}{c}0.002 \\
(0.055)\end{array}$ & $\begin{array}{c}0.002 \\
(0.058)\end{array}$ \\
\hline Long-term interest rate & $\begin{array}{c}0.004 \\
(0.002)\end{array}$ & $\begin{array}{l}0.003^{* *} \\
(0.001)\end{array}$ & $\begin{array}{l}0.005^{*} \\
(0.003)\end{array}$ \\
\hline Consol interest rate & $\begin{array}{l}0.017 \\
(0.011)\end{array}$ & $\begin{array}{c}0.014 \\
(0.016)\end{array}$ & $\begin{array}{c}0.021 \\
(0.017)\end{array}$ \\
\hline Gold standard dummy & $\begin{array}{c}0.022 \\
(0.017)\end{array}$ & $\begin{array}{c}0.006 \\
(0.013)\end{array}$ & $\begin{array}{c}0.015 \\
(0.012)\end{array}$ \\
\hline Growth of the money supply & $\begin{array}{l}-0.031 \\
(0.025)\end{array}$ & $\begin{array}{l}-0.020 \\
(0.017)\end{array}$ & $\begin{array}{l}-0.023 \\
(0.016)\end{array}$ \\
\hline Gold reserves/notes in circulation & $\begin{array}{c}-0.072^{\star *} \\
(0.035)\end{array}$ & $\begin{array}{l}-0.034 \\
(0.028)\end{array}$ & $\begin{array}{l}-0.057^{* *} \\
(0.027)\end{array}$ \\
\hline Currency crisis in $t$ & $\begin{array}{l}0.060^{\star *} \\
(0.026)\end{array}$ & $\begin{array}{c}0.031 \\
(0.022)\end{array}$ & $\begin{array}{l}0.075^{*} \\
(0.041)\end{array}$ \\
\hline Currency crisis in $t-1$ & $\begin{array}{l}-0.001 \\
(0.008)\end{array}$ & $\begin{array}{c}0.012 \\
(0.016)\end{array}$ & $\begin{array}{l}0.0004 \\
(0.010)\end{array}$ \\
\hline Banking crisis in $t$ & $\begin{array}{c}0.017 \\
(0.013)\end{array}$ & $\begin{array}{l}-0.004 \\
(0.010)\end{array}$ & $\begin{array}{c}0.038 \\
(0.031)\end{array}$ \\
\hline Banking crisis in $t$ - 1 & $\begin{array}{c}0.049 \\
(0.033)\end{array}$ & $\begin{array}{l}0.034 \\
(0.021)\end{array}$ & $\begin{array}{c}0.015 \\
(0.017)\end{array}$ \\
\hline constant & $\begin{array}{l}-4.11 \\
(3.52)\end{array}$ & $\begin{array}{c}-4.72 \\
(2.35)^{\star \star}\end{array}$ & $\begin{array}{c}-6.33 \\
(2.77)^{\star *}\end{array}$ \\
\hline Number of obs & 530 & 530 & 530 \\
\hline Percentage of Correct Positives & 83.3 & 66.7 & 83.3 \\
\hline Percentage of Correct Negatives & 98 & 98.6 & 98.8 \\
\hline $\begin{array}{l}\text { Psuedo R-squared } \\
\text { log-likelihood value }\end{array}$ & $\begin{array}{c}0.64 \\
-11.93\end{array}$ & $\begin{array}{l}0.50 \\
-16.3\end{array}$ & $\begin{array}{c}0.56 \\
-14.3\end{array}$ \\
\hline
\end{tabular}

Notes: Dependent variable is a binary indicator for a debt crisis. Marginal effects of variables on the probability of a crisis are reported. Robust clustered standard errors

are in parentheses. See the text for precise definitions of variables. Positive signifies crisis year; ${ }^{*} p$ value $<0.1 ;{ }^{* \star} p$-value $<0.05 ;{ }^{* * *} p$-value $<0.01$ 
Table 2 Determinants of Debt Crises, 1972-1997

\begin{tabular}{|c|c|c|c|c|}
\hline Regressors & (1) & (2) & (3) & (4) \\
\hline Original Sin & $\begin{array}{c}0.016^{*} \\
(0.010)\end{array}$ & $\begin{array}{l}0.008^{*} \\
(0.005)\end{array}$ & $\begin{array}{c}0.002 \\
(0.002)\end{array}$ & --- \\
\hline Debt/Output & $\begin{array}{l}0.001^{* * *} \\
(0.0002)\end{array}$ & $\begin{array}{l}0.001^{* * *} \\
(0.0001)\end{array}$ & $\begin{array}{l}0.001^{* * *} \\
(0.0001)\end{array}$ & --- \\
\hline Debt/OutputPre-1970 Default & $\begin{array}{c}0.0001 \\
(0.0002)\end{array}$ & --- & --- & --- \\
\hline Pre-1970 Default & $\begin{array}{l}-0.034 \\
(0.043)\end{array}$ & --- & --- & --- \\
\hline Mismatch & $\begin{array}{l}-0.003 \\
(0.006)\end{array}$ & --- & --- & $\begin{array}{c}0.020^{\star * *} \\
(0.006)\end{array}$ \\
\hline In (real GDP per capita) & --- & --- & $\begin{array}{l}0.316^{\star *} \\
(0.145)\end{array}$ & --- \\
\hline square of In (real GDP per capita) & --- & --- & $\begin{array}{c}-0.019^{* *} \\
(0.009)\end{array}$ & --- \\
\hline Trade balance/GDP & $\begin{array}{c}0.002 \\
(0.001)\end{array}$ & $\begin{array}{c}0.002 \\
(0.001)\end{array}$ & $\begin{array}{c}0.001 \\
(0.001)\end{array}$ & $\begin{array}{l}-0.0001 \\
(0.002)\end{array}$ \\
\hline Long-term interest rate & $\begin{array}{c}0.009^{* * *} \\
(0.003)\end{array}$ & $\begin{array}{l}0.006^{* *} \\
(0.003)\end{array}$ & $\begin{array}{c}0.001 \\
(0.004)\end{array}$ & $\begin{array}{l}0.005^{\star *} \\
(0.002)\end{array}$ \\
\hline G7 average long term interest rate & $\begin{array}{c}0.004 \\
(0.004)\end{array}$ & $\begin{array}{c}0.004 \\
(0.004)\end{array}$ & $\begin{array}{c}0.005 \\
(0.158)\end{array}$ & $\begin{array}{c}0.007^{\star * *} \\
(0.003)\end{array}$ \\
\hline Pegged exchange rate regime & $\begin{array}{c}-0.033^{\star \star *} \\
(0.009)\end{array}$ & $\begin{array}{c}-0.025^{\star \star *} \\
(0.007)\end{array}$ & $\begin{array}{c}-0.018^{\star \star *} \\
(0.005)\end{array}$ & $\begin{array}{l}-0.008 \\
(0.015)\end{array}$ \\
\hline Currency crisis in $t$ & $\begin{array}{l}0.053^{*} \\
(0.030)\end{array}$ & $\begin{array}{l}0.049^{*} \\
(0.029)\end{array}$ & $\begin{array}{l}0.054^{* *} \\
(0.026)\end{array}$ & $\begin{array}{l}0.061^{*} \\
(0.036)\end{array}$ \\
\hline Currency crisis in $\mathrm{t}-1$ & $\begin{array}{c}0.045 \\
(0.028)\end{array}$ & $\begin{array}{c}0.034 \\
(0.023)\end{array}$ & $\begin{array}{c}0.024 \\
(0.015)\end{array}$ & $\begin{array}{l}0.071^{* *} \\
(0.033)\end{array}$ \\
\hline Banking crisis in $t$ & $\begin{array}{l}-0.000 \\
(0.016)\end{array}$ & $\begin{array}{c}0.005 \\
(0.015)\end{array}$ & $\begin{array}{c}0.009 \\
(0.013)\end{array}$ & $\begin{array}{c}0.010 \\
(0.018)\end{array}$ \\
\hline Banking crisis in $\mathrm{t}-1$ & $\begin{array}{c}0.020 \\
(0.018)\end{array}$ & $\begin{array}{c}0.016 \\
(0.017)\end{array}$ & $\begin{array}{c}0.014 \\
(0.016)\end{array}$ & $\begin{array}{c}0.002 \\
(0.022)\end{array}$ \\
\hline constant & $\begin{array}{l}-26.68 \\
(9.69)\end{array}$ & $\begin{array}{l}-26.77 \\
(9.69)\end{array}$ & $\begin{array}{c}-52.17 \\
(17.44)\end{array}$ & $\begin{array}{l}-4.42 \\
(0.63)\end{array}$ \\
\hline Number of obs & 520 & 530 & 524 & 571 \\
\hline Percentage of Correct Positives & 82.3 & 82.3 & 93.75 & 50 \\
\hline Percentage of Correct Negatives & 93.8 & 93.9 & 95.4 & 91.1 \\
\hline $\begin{array}{l}\text { Psuedo R-squared } \\
\text { log-likelihood value }\end{array}$ & $\begin{array}{l}0.50 \\
-37.82\end{array}$ & $\begin{array}{l}0.49 \\
-37.8\end{array}$ & $\begin{array}{c}.54 \\
-32.33\end{array}$ & $\begin{array}{l}0.25 \\
-64.55\end{array}$ \\
\hline
\end{tabular}

Notes: Dependent variable is a binary indicator for a debt crisis. Marginal effects of variables on the probability of a crisis are reported. Robust clustered standard errors are in parentheses.

See the text for precise definitions of variables. Positive signifies crisis year; ${ }^{*} p$-value $<0.1 ;{ }^{* *} p$-value $<0.05 ;{ }^{* * *} p$ value $<0.01$ 
Table 3 Determinants of Currency Crises, 1880-1913

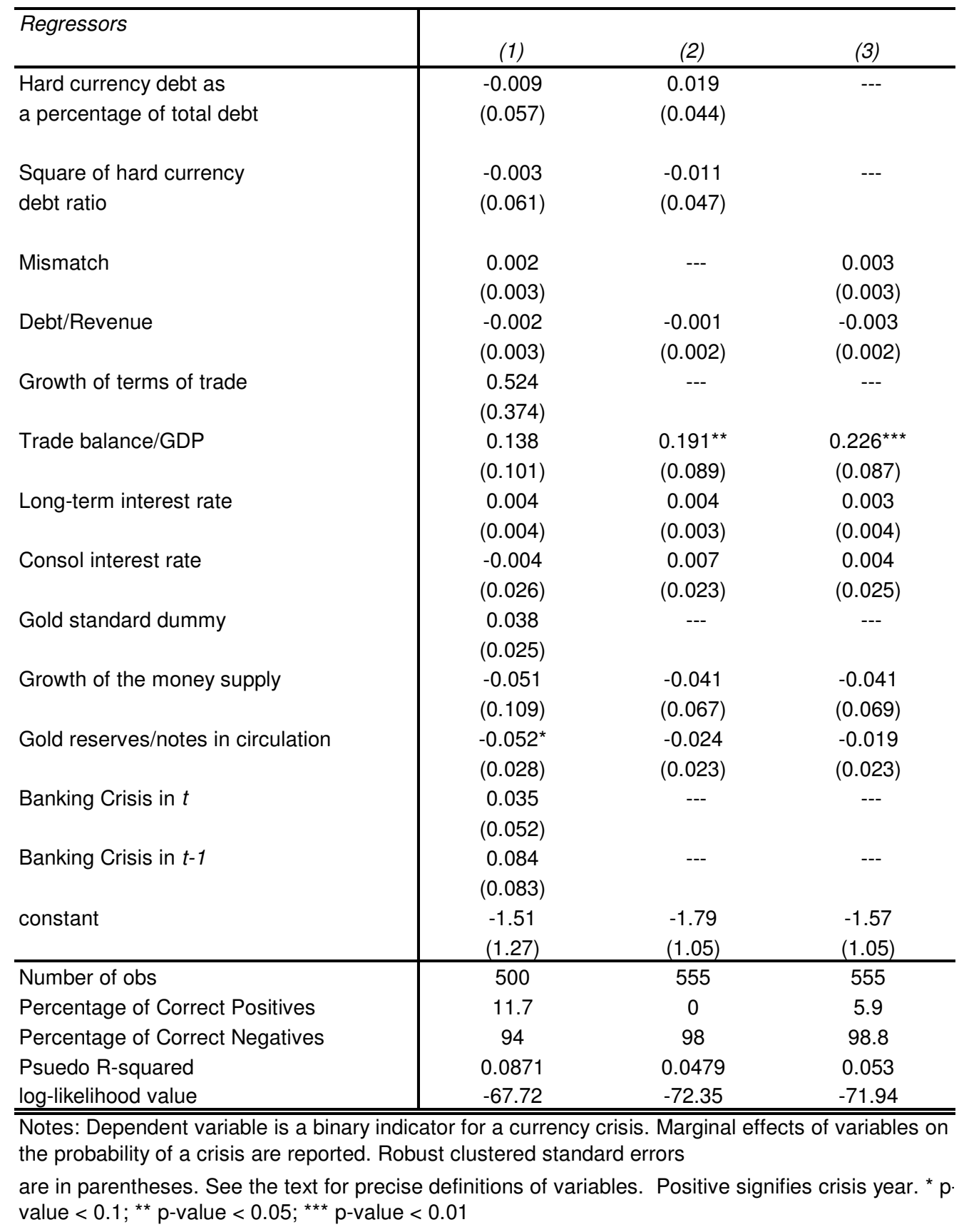


Table 4 Determinants of Currency Crises, 1972-1997

\begin{tabular}{|c|c|c|c|}
\hline Regressors & (1) & (2) & (3) \\
\hline Original Sin & $\begin{array}{l}0.0007 \\
(0.001)\end{array}$ & $\begin{array}{l}0.001^{\star *} \\
(0.001)\end{array}$ & --- \\
\hline Mismatch & $\begin{array}{c}0.040^{* * *} \\
(0.013)\end{array}$ & --- & $\begin{array}{l}0.032^{* * *} \\
(0.011)\end{array}$ \\
\hline Debt/Output & $\begin{array}{l}0.001^{* *} \\
(0.000)\end{array}$ & $\begin{array}{l}0.001^{* * *} \\
(0.000)\end{array}$ & $\begin{array}{c}0.0004 \\
(0.0003)\end{array}$ \\
\hline Growth of terms of trade & $\begin{array}{l}-0.001 \\
(0.002)\end{array}$ & --- & --- \\
\hline Trade balance/GDP & $\begin{array}{c}-0.007^{* *} \\
(0.003)\end{array}$ & $\begin{array}{c}-0.007^{* * *} \\
(0.003)\end{array}$ & $\begin{array}{c}-0.007^{* * *} \\
(0.003)\end{array}$ \\
\hline Pegged exchnage rate regime & $\begin{array}{c}0.066 \\
(0.057)\end{array}$ & --- & --- \\
\hline Long-term interest rate & $\begin{array}{l}0.022^{* * *} \\
(0.007)\end{array}$ & $\begin{array}{c}0.012^{* * *} \\
(0.004)\end{array}$ & $\begin{array}{c}0.014^{* * *} \\
(0.003)\end{array}$ \\
\hline G7 average long term interest rate & $\begin{array}{l}-0.012^{*} \\
(0.007)\end{array}$ & $\begin{array}{l}-0.010 \\
(0.007)\end{array}$ & $\begin{array}{l}-0.007 \\
(0.006)\end{array}$ \\
\hline Growth of the money supply & $\begin{array}{c}0.00005^{* * *} \\
(0.00001)\end{array}$ & $\begin{array}{l}0.0001^{* * *} \\
(0.00004)\end{array}$ & $\begin{array}{c}0.00006^{* * *} \\
(0.00001)\end{array}$ \\
\hline M2 / Reserves & $\begin{array}{c}0.007^{* * *} \\
(0.002)\end{array}$ & $\begin{array}{c}0.007^{\star * *} \\
(0.001)\end{array}$ & $\begin{array}{l}-0.001 \\
(0.001)\end{array}$ \\
\hline Banking Crisis in $t$ & $\begin{array}{l}-0.038 \\
(0.054)\end{array}$ & --- & $\begin{array}{l}-0.063 \\
(0.048)\end{array}$ \\
\hline Banking Crisis in $t-1$ & $\begin{array}{c}0.095 \\
(0.078)\end{array}$ & --- & $\begin{array}{c}0.096 \\
(0.071)\end{array}$ \\
\hline constant & $\begin{array}{l}-2.83 \\
(0.55)\end{array}$ & $\begin{array}{l}-2.22 \\
(0.35)\end{array}$ & $\begin{array}{l}-1.76 \\
(0.31)\end{array}$ \\
\hline Number of obs & 419 & 609 & 641 \\
\hline Percentage of Correct Positives & 83.6 & 89.4 & 77.9 \\
\hline Percentage of Correct Negatives & 52.7 & 37.4 & 46.1 \\
\hline $\begin{array}{l}\text { Psuedo R-squared } \\
\text { log-likelihood value }\end{array}$ & $\begin{array}{c}0.13 \\
-150.71\end{array}$ & $\begin{array}{c}0.07 \\
-226.56\end{array}$ & $\begin{array}{c}0.082 \\
-232.44\end{array}$ \\
\hline
\end{tabular}

Notes: Dependent variable is a binary indicator for a currency crisis. Marginal effects of variables on the probability of a crisis are reported. Robust clustered standard errors

are in parentheses. See the text for precise definitions of variables. Positive signifies crisis year. ${ }^{*} p$-value $<0.1 ;{ }^{* *} p$-value $<0.05 ;{ }^{* *} p$-value $<0.01$ 
Table 5 Determinants of Banking Crises, 1880-1913

\begin{tabular}{|c|c|c|c|}
\hline Regressors & (1) & (2) & (3) \\
\hline $\begin{array}{l}\text { Hard currency debt as } \\
\text { a percentage of total debt }\end{array}$ & $\begin{array}{c}0.018 \\
(0.075)\end{array}$ & $\begin{array}{l}0.035 \\
(0.067)\end{array}$ & --- \\
\hline $\begin{array}{l}\text { Square of hard currency } \\
\text { debt ratio }\end{array}$ & $\begin{array}{l}-0.024 \\
(0.078)\end{array}$ & $\begin{array}{l}-0.037 \\
(0.072)\end{array}$ & --- \\
\hline Debt/Revenue & $\begin{array}{l}-0.002 \\
(0.003)\end{array}$ & $\begin{array}{r}-0.0002 \\
(0.002)\end{array}$ & $\begin{array}{l}-0.002 \\
(0.003)\end{array}$ \\
\hline Mismatch & $\begin{array}{c}0.004 \\
(0.003)\end{array}$ & --- & $\begin{array}{c}0.004 \\
(0.004)\end{array}$ \\
\hline Growth of terms of trade & $\begin{array}{l}-0.592 \\
(0.381)\end{array}$ & $\begin{array}{l}-0.542 \\
(0.378)\end{array}$ & $\begin{array}{l}-0.578 \\
(0.387)\end{array}$ \\
\hline Trade balance/GDP & $\begin{array}{l}0.364^{\star *} \\
(0.176)\end{array}$ & $\begin{array}{l}0.323^{* *} \\
(0.160)\end{array}$ & $\begin{array}{l}0.356^{\star *} \\
(0.163)\end{array}$ \\
\hline Gold standard dummy & $\begin{array}{l}-0.006 \\
(0.022)\end{array}$ & $\begin{array}{c}0.000 \\
(0.019)\end{array}$ & $\begin{array}{l}-0.010 \\
(0.020)\end{array}$ \\
\hline Growth of the money supply & $\begin{array}{c}0.038 \\
(0.069)\end{array}$ & $\begin{array}{c}0.030 \\
(0.071)\end{array}$ & $\begin{array}{c}0.029 \\
(0.072)\end{array}$ \\
\hline Gold reserves/notes in circulation & $\begin{array}{c}0.025 \\
(0.030)\end{array}$ & $\begin{array}{c}0.026 \\
(0.024)\end{array}$ & $\begin{array}{r}0.038 \\
(0.029)\end{array}$ \\
\hline Long-term interest rate & $\begin{array}{l}0.004 \\
(0.005)\end{array}$ & $\begin{array}{c}0.006 \\
(0.006)\end{array}$ & $\begin{array}{l}0.004 \\
(0.005)\end{array}$ \\
\hline Consol interest rate & $\begin{array}{c}0.023 \\
(0.026)\end{array}$ & $\begin{array}{c}0.026 \\
(0.026)\end{array}$ & $\begin{array}{c}0.024 \\
(0.025)\end{array}$ \\
\hline Currency crisis in $t$ & $\begin{array}{c}0.073 \\
(0.070)\end{array}$ & $\begin{array}{c}0.079 \\
(0.075)\end{array}$ & $\begin{array}{c}0.075 \\
(0.072)\end{array}$ \\
\hline Currency crisis in $t-1$ & $\begin{array}{c}0.072 \\
(0.075)\end{array}$ & $\begin{array}{c}0.068 \\
(0.074)\end{array}$ & $\begin{array}{c}0.073 \\
(0.080)\end{array}$ \\
\hline constant & $\begin{array}{l}-2.75 \\
(0.94) \\
\end{array}$ & $\begin{array}{l}-2.94 \\
(0.89)\end{array}$ & $\begin{array}{l}-2.75 \\
(0.92) \\
\end{array}$ \\
\hline Number of obs & 496 & 496 & 496 \\
\hline Percentage of Correct Positives & 16.6 & 22.2 & 16.6 \\
\hline Percentage of Correct Negatives & 96.6 & 96.8 & 96.4 \\
\hline $\begin{array}{l}\text { Psuedo R-squared } \\
\text { log-likelihood value }\end{array}$ & $\begin{array}{c}0.07 \\
-71.56\end{array}$ & $\begin{array}{c}0.07 \\
-71.99\end{array}$ & $\begin{array}{c}0.07 \\
-71.63\end{array}$ \\
\hline
\end{tabular}

Notes: Dependent variable is a binary indicator for a banking crisis. Marginal effects of variables on the probability of a crisis are reported. Robust clustered standard errors are in parentheses. See the text for precise definitions of variables.

Positive signifies crisis year. ${ }^{*} p$-value $<0.1$; ${ }^{* *} p$-value $<0.05 ;{ }^{* * *} p$-value $<0.01$ 
Table 6 Determinants of Banking Crises, 1972-1997

\begin{tabular}{|c|c|c|c|c|}
\hline Regressors & (1) & (2) & (3) & (4) \\
\hline Original Sin & $\begin{array}{c}0.001 \\
(0.001)\end{array}$ & $\begin{array}{c}0.001 \\
(0.001)\end{array}$ & $\begin{array}{c}0.050^{\star \star \star} \\
(0.016)\end{array}$ & $\overline{---}$ \\
\hline Mismatch & $\begin{array}{c}0.017 \\
(0.011)\end{array}$ & --- & --- & $\begin{array}{l}0.020^{\star *} \\
(0.010)\end{array}$ \\
\hline Original Sin * In(real GDP per capita) & --- & --- & $\begin{array}{c}-0.005^{\star * *} \\
(0.002)\end{array}$ & --- \\
\hline In(real GDP per capita) & --- & --- & $\begin{array}{c}0.496^{\star * \star} \\
(0.158)\end{array}$ & --- \\
\hline Debt/Output & $\begin{array}{l}-0.0004 \\
(0.0005)\end{array}$ & $\begin{array}{r}-0.0001 \\
(0.004)\end{array}$ & $\begin{array}{c}-0.0003 \\
(0.0004)\end{array}$ & $\begin{array}{l}-0.0002 \\
(0.0003)\end{array}$ \\
\hline Growth of terms of trade & $\begin{array}{l}-0.001 \\
(0.001)\end{array}$ & $\begin{array}{l}-0.001 \\
(0.001)\end{array}$ & $\begin{array}{l}-0.001 \\
(0.001)\end{array}$ & $\begin{array}{l}-0.001 \\
(0.001)\end{array}$ \\
\hline Trade balance/GDP & $\begin{array}{c}-0.006^{\star \star} \\
(0.003)\end{array}$ & $\begin{array}{l}-0.004 \\
(0.002)\end{array}$ & $\begin{array}{c}-0.006^{* *} \\
(0.003)\end{array}$ & $\begin{array}{l}-0.003 \\
(0.002)\end{array}$ \\
\hline Pegged exchnage rate regime & $\begin{array}{l}-0.002 \\
(0.023)\end{array}$ & $\begin{array}{l}-0.008 \\
(0.021)\end{array}$ & $\begin{array}{l}-0.015 \\
(0.020)\end{array}$ & $\begin{array}{c}0.014 \\
(0.021)\end{array}$ \\
\hline Growth of the money supply & $\begin{array}{c}0.00005^{\star} \\
(0.0003)\end{array}$ & $\begin{array}{c}0.00007^{\star \star *} \\
(0.00002)\end{array}$ & $\begin{array}{l}0.0007^{\star * *} \\
(0.00002)\end{array}$ & $\begin{array}{c}0.00006^{*} \\
(0.00003)\end{array}$ \\
\hline M2 / Reserves & $\begin{array}{c}0.001 \\
(0.002)\end{array}$ & $\begin{array}{c}0.002 \\
(0.002)\end{array}$ & $\begin{array}{c}0.002 \\
(0.002)\end{array}$ & $\begin{array}{r}0.00006 \\
(0.00007)\end{array}$ \\
\hline Long-term interest rate & $\begin{array}{c}0.013^{\star \star \star} \\
(0.005)\end{array}$ & $\begin{array}{l}0.011^{\star *} \\
(0.004)\end{array}$ & $\begin{array}{l}0.014^{\star *} \\
(0.007)\end{array}$ & $\begin{array}{l}0.008^{\star} \\
(0.005)\end{array}$ \\
\hline G7 average long term interest rate & $\begin{array}{l}0.0001 \\
(0.006)\end{array}$ & $\begin{array}{c}0.002 \\
(0.006)\end{array}$ & $\begin{array}{l}-0.002 \\
(0.007)\end{array}$ & $\begin{array}{c}0.002 \\
(0.007)\end{array}$ \\
\hline Currency crisis in $t$ & $\begin{array}{l}-0.015 \\
(0.032)\end{array}$ & $\begin{array}{l}-0.012 \\
(0.031)\end{array}$ & $\begin{array}{l}-0.012 \\
(0.032)\end{array}$ & $\begin{array}{l}-0.026 \\
(0.028)\end{array}$ \\
\hline Currency crisis in $t$ - 1 & $\begin{array}{l}-0.021 \\
(0.032)\end{array}$ & $\begin{array}{l}-0.023 \\
(0.029)\end{array}$ & $\begin{array}{l}-0.021 \\
(0.029)\end{array}$ & $\begin{array}{l}-0.032 \\
(0.028)\end{array}$ \\
\hline constant & $\begin{array}{l}-3.54 \\
(0.91) \\
\end{array}$ & $\begin{array}{l}-3.85 \\
(1.00) \\
\end{array}$ & $\begin{array}{r}-53.78 \\
(16.6) \\
\end{array}$ & $\begin{array}{l}-2.72 \\
(0.58) \\
\end{array}$ \\
\hline Number of obs & 345 & 367 & 367 & 405 \\
\hline Percentage of Correct Positives & 40 & 40 & 50 & 32 \\
\hline Percentage of Correct Negatives & 85.8 & 88.1 & 87.3 & 85.5 \\
\hline $\begin{array}{l}\text { Psuedo R-squared } \\
\text { log-likelihood value }\end{array}$ & $\begin{array}{c}0.11 \\
-68.13\end{array}$ & $\begin{array}{l}0.091 \\
-70.56\end{array}$ & $\begin{array}{c}0.13 \\
-67.18\end{array}$ & $\begin{array}{c}0.07 \\
-87.57\end{array}$ \\
\hline
\end{tabular}

Notes: Dependent variable is a binary indicator for a banking crisis. Marginal effects of variables on the probability of a crisis are reported. Robust clustered standard errors are in parentheses.

See the text for precise definitions of variables. Positive signifies crisis year. ${ }^{*} p$-value $<0.1$; ${ }^{* *} p$-value $<0.05$; ${ }^{* * *} p$ value $<0.01$ 
Table 7 Fixed Effects Estimations, 1880-1913

\begin{tabular}{|c|c|c|c|}
\hline Regressors & $\begin{array}{c}\text { Debt Crises } \\
\text { (1) }\end{array}$ & $\begin{array}{c}\text { Currency Crises } \\
\text { (2) }\end{array}$ & $\begin{array}{c}\text { Banking Crises } \\
\text { (3) }\end{array}$ \\
\hline $\begin{array}{l}\text { Hard currency debt as } \\
\text { a percentage of total debt }\end{array}$ & $\begin{array}{c}0.112 \\
(0.095)\end{array}$ & $\begin{array}{l}-0.142 \\
(0.141)\end{array}$ & $\begin{array}{c}0.158 \\
(0.152)\end{array}$ \\
\hline $\begin{array}{l}\text { Square of hard currency } \\
\text { debt ratio }\end{array}$ & $\begin{array}{l}-0.127 \\
(0.093)\end{array}$ & $\begin{array}{l}-0.084 \\
(0.139)\end{array}$ & $\begin{array}{l}-0.150 \\
(0.152)\end{array}$ \\
\hline Debt/Revenue & $\begin{array}{c}0.017^{\star * \star} \\
(0.005)\end{array}$ & $\begin{array}{l}0.0001 \\
(0.008)\end{array}$ & $\begin{array}{l}-0.006 \\
(0.009)\end{array}$ \\
\hline Mismatch & $\begin{array}{l}-0.001 \\
(0.010)\end{array}$ & $\begin{array}{c}0.012 \\
(0.009)\end{array}$ & $\begin{array}{c}0.027^{* * *} \\
(0.010)\end{array}$ \\
\hline Square of mismatch & $\begin{array}{l}-0.001^{*} \\
(0.000)\end{array}$ & --- & --- \\
\hline Growth of terms of trade & $\begin{array}{l}-0.303 \\
(0.343)\end{array}$ & $\begin{array}{l}0.716 \\
(0.577)\end{array}$ & $\begin{array}{l}-0.677 \\
(0.591)\end{array}$ \\
\hline Trade balance/GDP & $\begin{array}{l}-0.313^{*} \\
(0.162)\end{array}$ & $\begin{array}{l}0.030 \\
(0.279)\end{array}$ & $\begin{array}{c}0.405 \\
(0.285)\end{array}$ \\
\hline long term interest rate & $\begin{array}{l}0.046^{* * *} \\
(0.007)\end{array}$ & $\begin{array}{c}0.002 \\
(0.009)\end{array}$ & $\begin{array}{c}0.006 \\
(0.009)\end{array}$ \\
\hline Gold standard dummy & $\begin{array}{l}-0.013 \\
(0.023)\end{array}$ & $\begin{array}{c}0.004 \\
(0.039)\end{array}$ & $\begin{array}{l}-0.076^{*} \\
(0.039)\end{array}$ \\
\hline Growth of the money supply & $\begin{array}{l}-0.031 \\
(0.055)\end{array}$ & $\begin{array}{l}-0.116 \\
(0.087)\end{array}$ & $\begin{array}{c}0.155 \\
(0.096)\end{array}$ \\
\hline Gold reserves/notes in circulation & $\begin{array}{l}0.040 \\
(0.034)\end{array}$ & $\begin{array}{l}0.023 \\
(0.059)\end{array}$ & $\begin{array}{l}0.021 \\
(0.060)\end{array}$ \\
\hline Consol & $\begin{array}{c}0.094^{\star * *} \\
(0.026)\end{array}$ & $\begin{array}{r}-0.0001 \\
(0.044)\end{array}$ & $\begin{array}{c}0.055 \\
(0.044)\end{array}$ \\
\hline Currency Crisis in $t$ & $\begin{array}{l}0.089^{* \star *} \\
(0.027)\end{array}$ & --- & $\begin{array}{l}0.077^{*} \\
(0.047)\end{array}$ \\
\hline Currnecy Crisis in $t-1$ & $\begin{array}{c}0.034 \\
(0.029)\end{array}$ & --- & $\begin{array}{c}0.072 \\
(0.050)\end{array}$ \\
\hline Banking Crisis in $t$ & $\begin{array}{l}0.011 \\
(0.025)\end{array}$ & $\begin{array}{l}0.041 \\
(0.041)\end{array}$ & --- \\
\hline Banking Crisis in $t-1$ & $\begin{array}{l}0.043^{*} \\
(0.024)\end{array}$ & $\begin{array}{l}0.087^{\star *} \\
(0.040)\end{array}$ & --- \\
\hline constant & $\begin{array}{c}-0.322^{\star \star \star} \\
(0.086) \\
\end{array}$ & $\begin{array}{r}0.103 \\
(0.151) \\
\end{array}$ & $\begin{array}{l}-0.106 \\
(0.153) \\
\end{array}$ \\
\hline Number of obs & 478 & 500 & 496 \\
\hline R-squared & 0.1 & 0.0012 & 0.01 \\
\hline F-stat & $7.86^{\star \star \star}$ & 1.23 & $2.32^{\star \star *}$ \\
\hline
\end{tabular}

Notes: Dependent variable is a binary indicator for a banking crisis. Estimation is by OLS with country indicators. See the text for precise definitions of variables. R-squared

is the overall $\mathrm{R}$-squared. ${ }^{*} p$-value $<0.1 ;{ }^{* *} p$-value $<0.05 ;{ }^{* * *} p$-value $<0.01$ 
Table 8 Fixed Effects Estimations, 1972-1997

\begin{tabular}{|c|c|c|c|}
\hline Regressors & $\begin{array}{c}\text { Debt Crises } \\
\text { (1) }\end{array}$ & $\begin{array}{c}\text { Currency Crises } \\
\text { (2) }\end{array}$ & $\begin{array}{l}\text { Banking Crises } \\
\text { (3) }\end{array}$ \\
\hline Mismatch & $\begin{array}{l}-0.001 \\
(0.012)\end{array}$ & $\begin{array}{l}0.057^{\star \star} \\
(0.025)\end{array}$ & $\begin{array}{c}0.031 \\
(0.023)\end{array}$ \\
\hline Debt/Output & $\begin{array}{l}0.002^{* * *} \\
(0.001)\end{array}$ & $\begin{array}{c}0.001 \\
(0.001)\end{array}$ & $\begin{array}{l}-0.001 \\
(0.001)\end{array}$ \\
\hline Trade balance/GDP & $\begin{array}{l}0.001 \\
(0.002)\end{array}$ & $\begin{array}{l}-0.009^{\star *} \\
(0.004)\end{array}$ & $\begin{array}{l}-0.005 \\
(0.004)\end{array}$ \\
\hline Growth of terms of trade & --- & $\begin{array}{l}-0.001 \\
(0.001)\end{array}$ & $\begin{array}{l}-0.0006 \\
(0.001)\end{array}$ \\
\hline M2 / Reserves & --- & $\begin{array}{c}-0.0 \\
(0.0004)\end{array}$ & $\begin{array}{l}-0.0001 \\
(0.0003)\end{array}$ \\
\hline G7 average long term interest rate & $\begin{array}{l}0.007 \\
(0.005)\end{array}$ & $\begin{array}{c}0.003 \\
(0.012)\end{array}$ & $\begin{array}{l}-0.003 \\
(0.010)\end{array}$ \\
\hline Long-term interest rate & $\begin{array}{c}0.004 \\
(0.005)\end{array}$ & $\begin{array}{c}0.009 \\
(0.011)\end{array}$ & $\begin{array}{c}0.012 \\
(0.009)\end{array}$ \\
\hline Pegged exchnage rate regime & $\begin{array}{c}0.005 \\
(0.025)\end{array}$ & $\begin{array}{c}0.047 \\
(0.060)\end{array}$ & $\begin{array}{c}0.010 \\
(0.050)\end{array}$ \\
\hline Growth of the money supply & --- & $\begin{array}{l}0.00009^{*} \\
(0.00005)\end{array}$ & $\begin{array}{l}0.00009 \\
(0.0001)\end{array}$ \\
\hline Currency Crisis in $t$ & $\begin{array}{l}0.057^{\star *} \\
(0.024)\end{array}$ & --- & $\begin{array}{l}-0.016 \\
(0.040)\end{array}$ \\
\hline Currnecy Crisis in $t-1$ & $\begin{array}{l}0.069^{\star \star \star *} \\
(0.023)\end{array}$ & --- & $\begin{array}{l}-0.025 \\
(0.040)\end{array}$ \\
\hline Banking Crisis in $t$ & $\begin{array}{c}0.007 \\
(0.027)\end{array}$ & $\begin{array}{l}-0.038 \\
(0.054)\end{array}$ & --- \\
\hline Banking Crisis in $t-1$ & $\begin{array}{c}0.034 \\
(0.028)\end{array}$ & $\begin{array}{c}0.079 \\
(0.056)\end{array}$ & --- \\
\hline constant & $\begin{array}{c}-0.167^{\star \star \star} \\
(0.045) \\
\end{array}$ & $\begin{array}{l}-0.148 \\
(0.114) \\
\end{array}$ & $\begin{array}{l}-0.026 \\
(0.094) \\
\end{array}$ \\
\hline Number of obs & $\begin{array}{l}571 \\
009\end{array}$ & $\begin{array}{l}491 \\
0.05\end{array}$ & $\begin{array}{l}405 \\
0.02\end{array}$ \\
\hline $\begin{array}{l}\text { R-squared } \\
\text { F-stat }\end{array}$ & $\begin{array}{c}0.09 \\
5.96^{\star * *}\end{array}$ & $2.64^{\star \star \star}$ & $\begin{array}{l}0.02 \\
0.77\end{array}$ \\
\hline
\end{tabular}

Notes: Dependent variable is a binary indicator for a banking crisis. Estimation is by OLS with country indicators. See the text for precise definitions of variables. R-squared is the overall R-squared. ${ }^{*} \mathrm{p}$-value $<0.1 ;{ }^{* *} \mathrm{p}$-value $<0.05 ;{ }^{* * *} \mathrm{p}$-value $<0.01$ 
Figure 1 Hard Currency Debt as a Percentage of Total Public Debt, 1880-1913

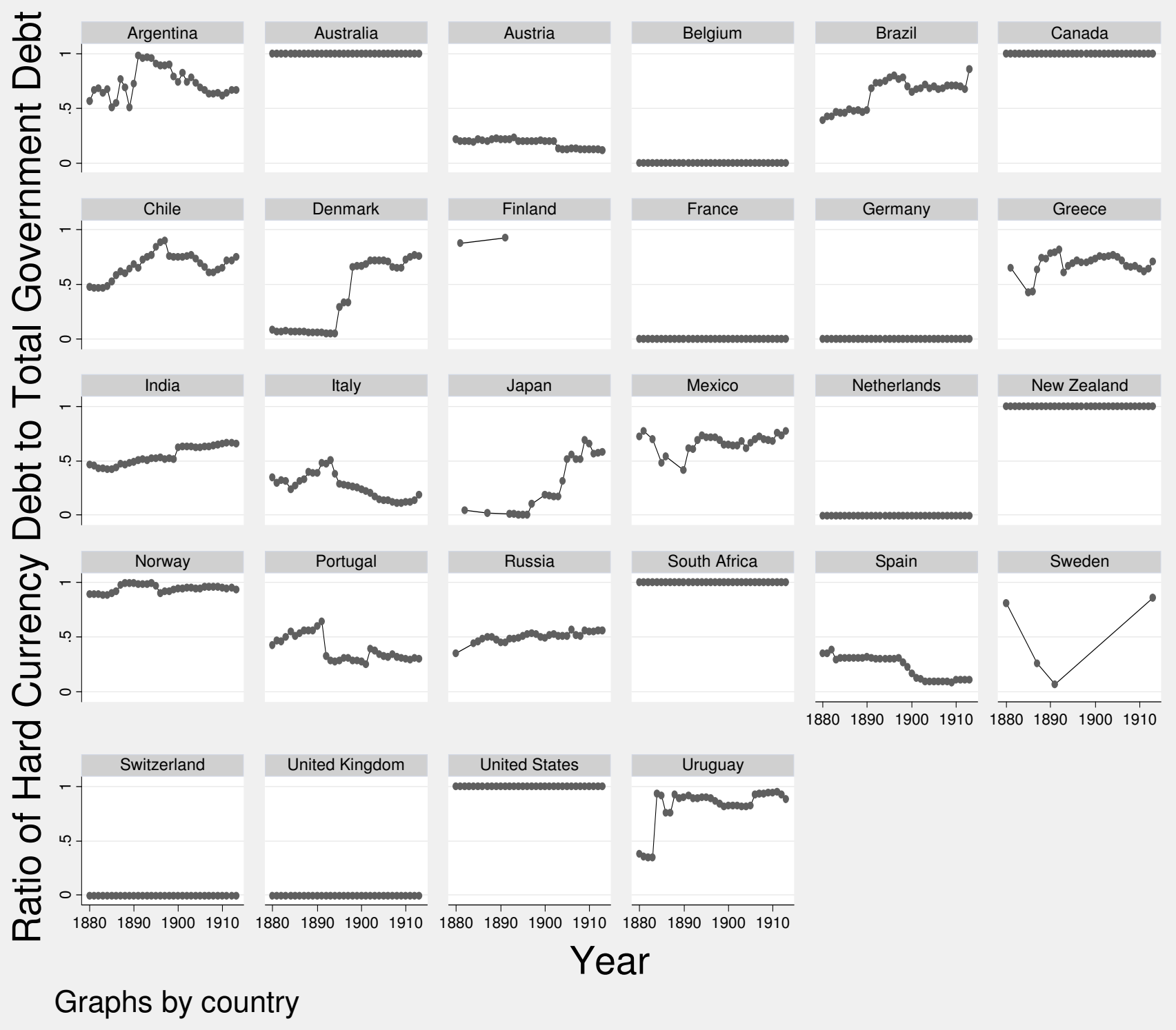


Figure 2 The Evolution of Original Sin in Sample Countries 1993-1997

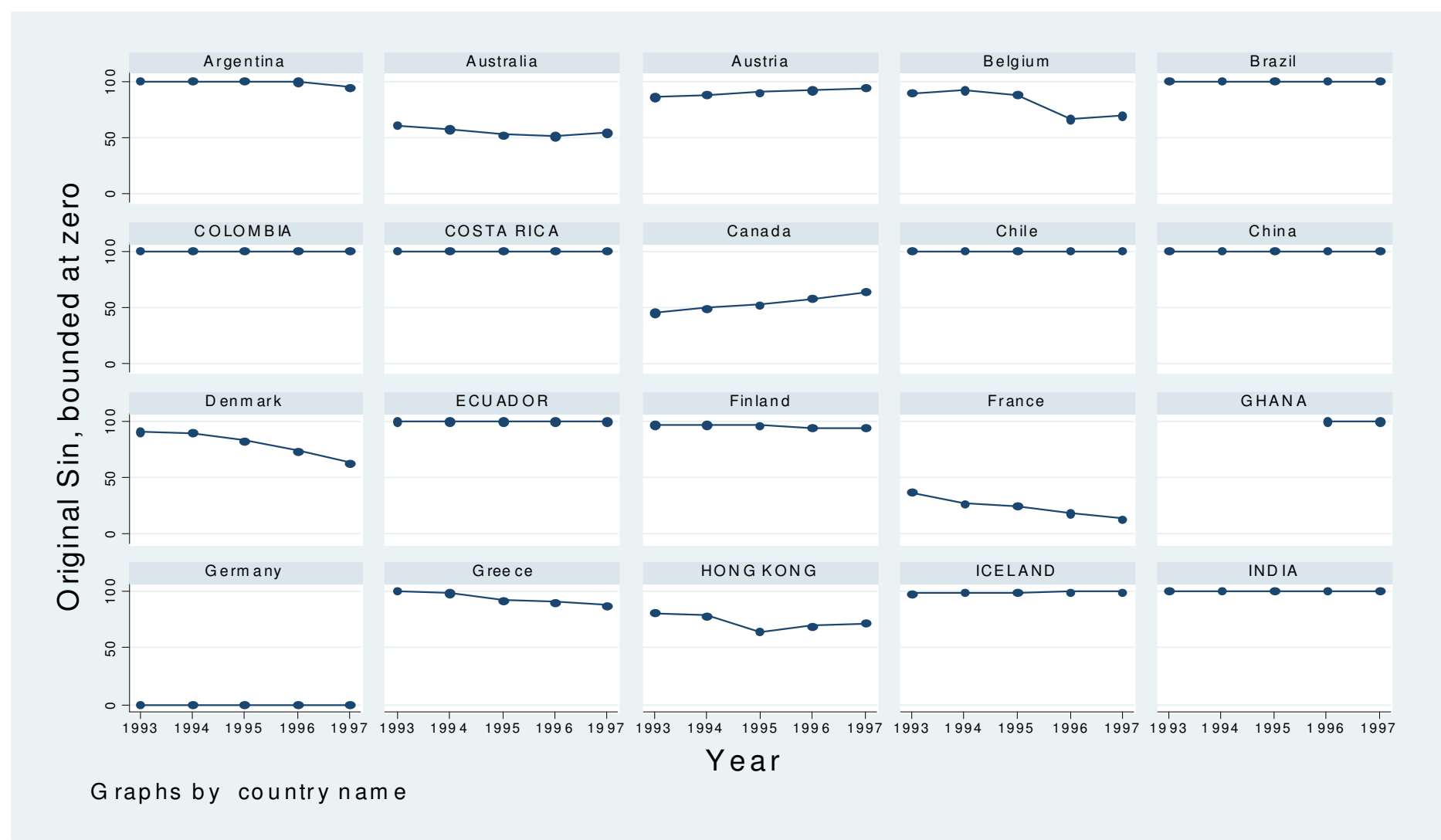

Notes: Data source is Eichengreen, Hausmann, and Panizza (2004). 
Figure 2 (cont.) The Evolution of Original Sin in Sample Countries 1993-1997

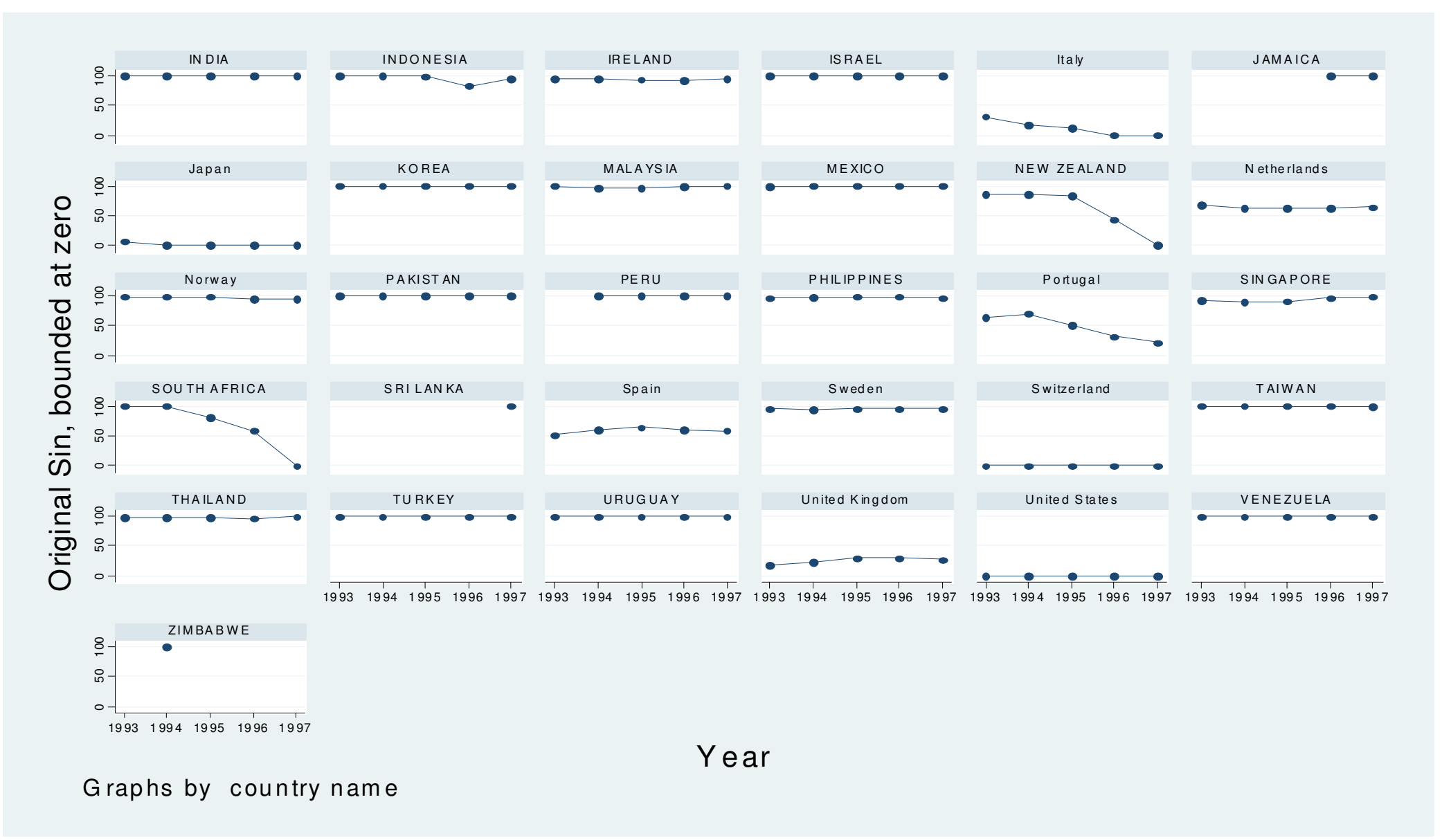


Figure 3 Average Ratio of Hard Currency Public Debt to Total Public Debt, 1880-1913

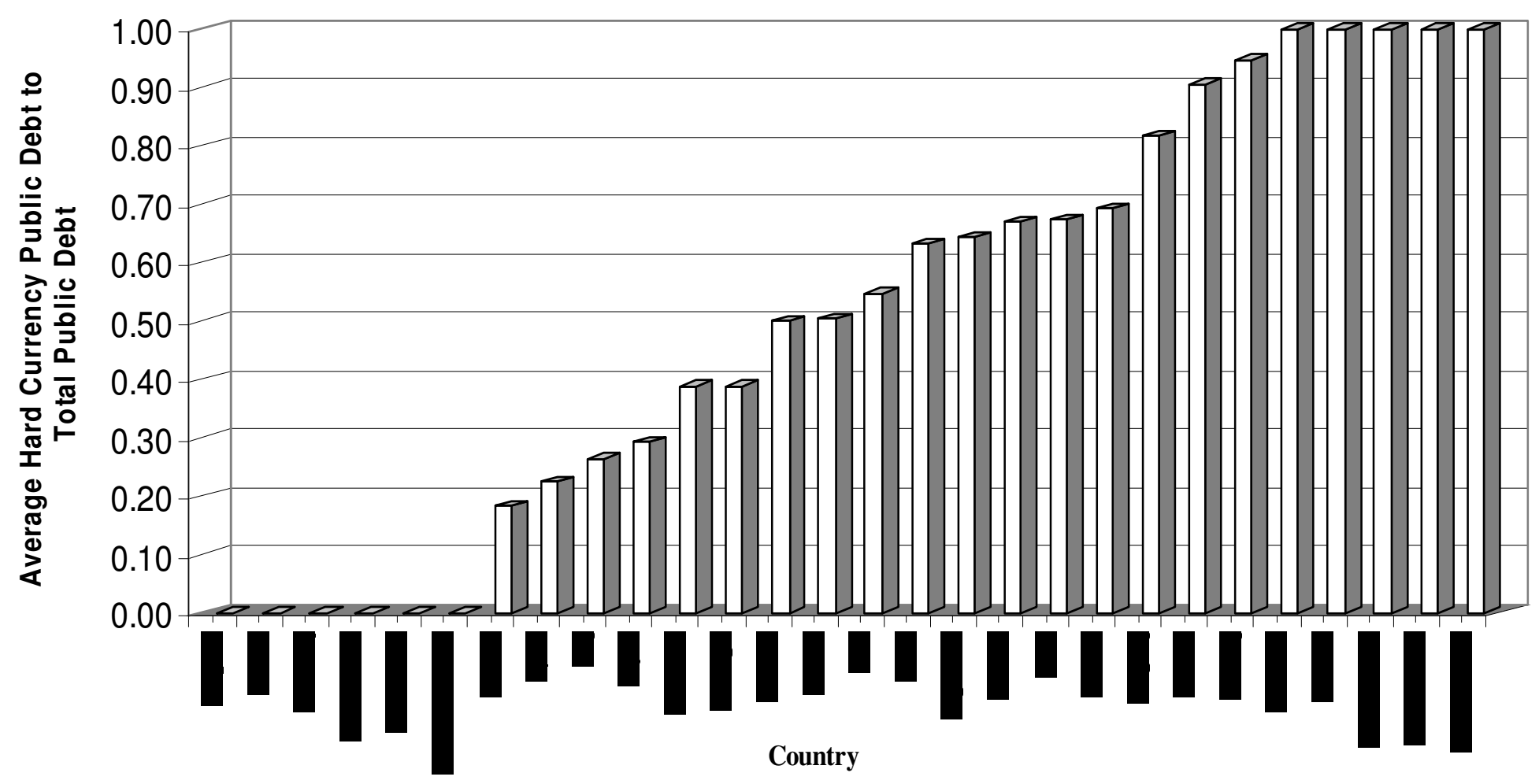


Figure 4 Average Level of Original Sin Between 1993 and 1997

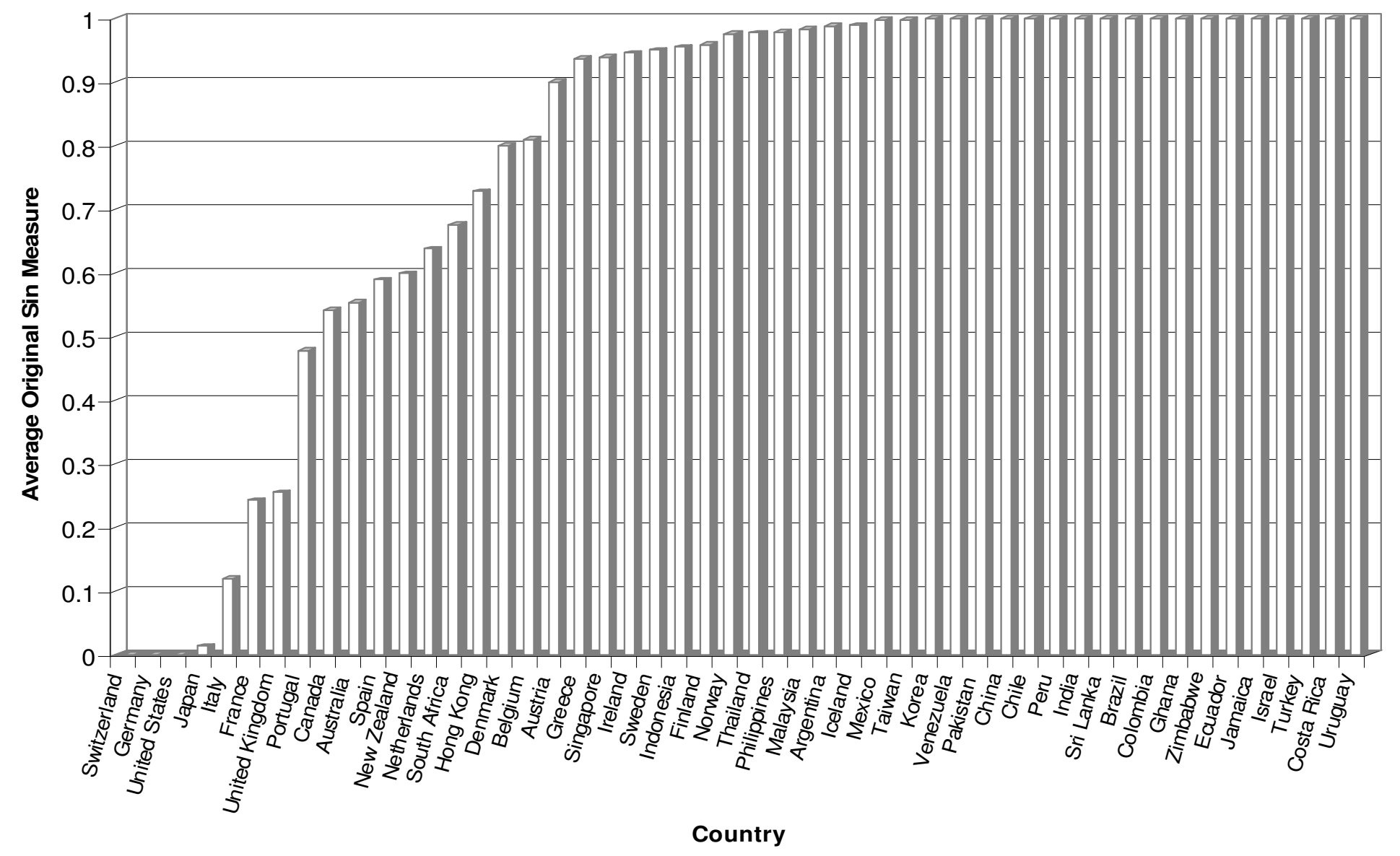

Notes: Data come from Eichengreen, Hausmann and Panizza (2005) 
Figure 5 Crisis Frequency in Percentage Probability per Year, 1880-1913 vs 19721997.

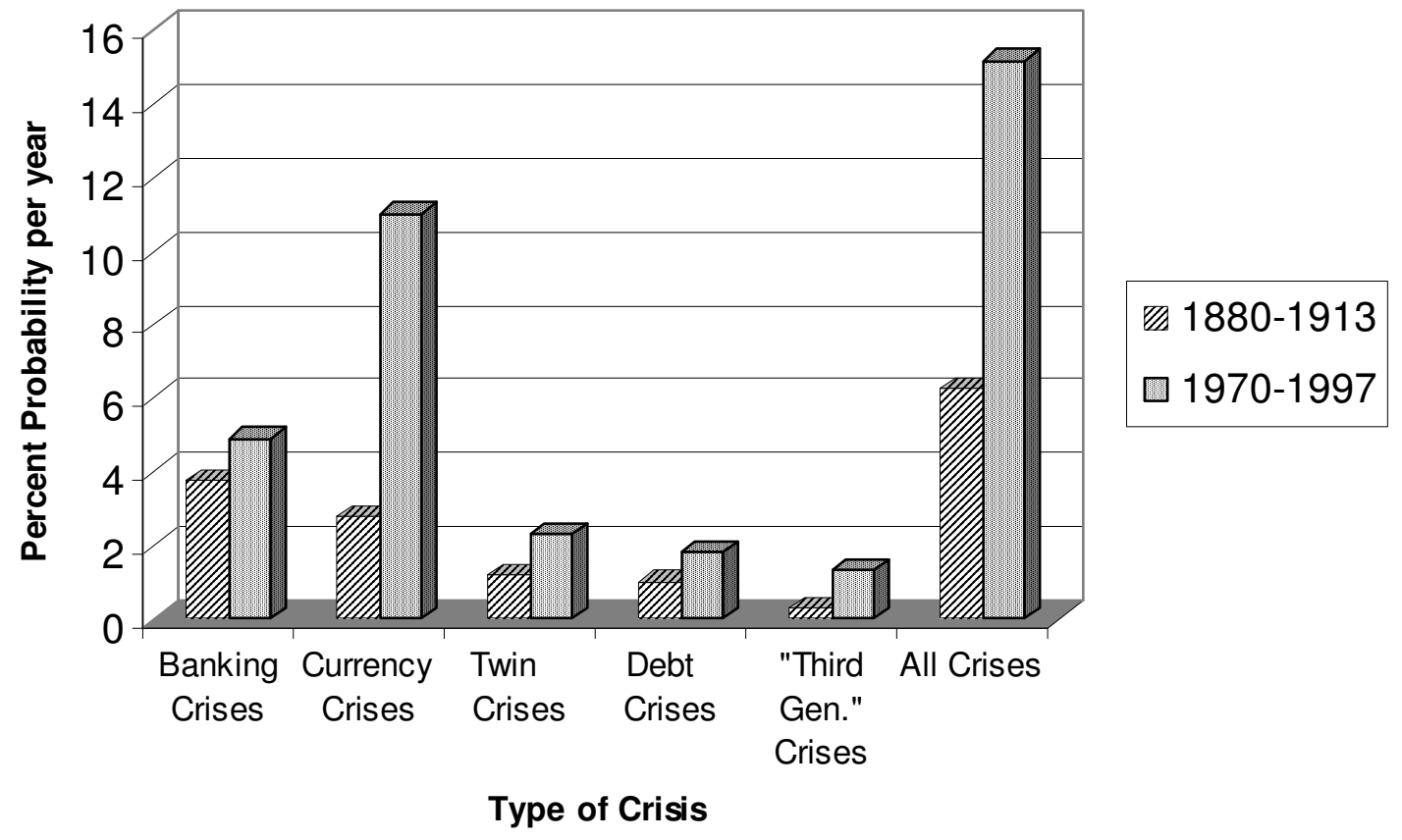


Figure 6 Crisis Frequencies By Country versus the Average Level of Hard Currency Public Debt to Total Public Debt, 1880-1913

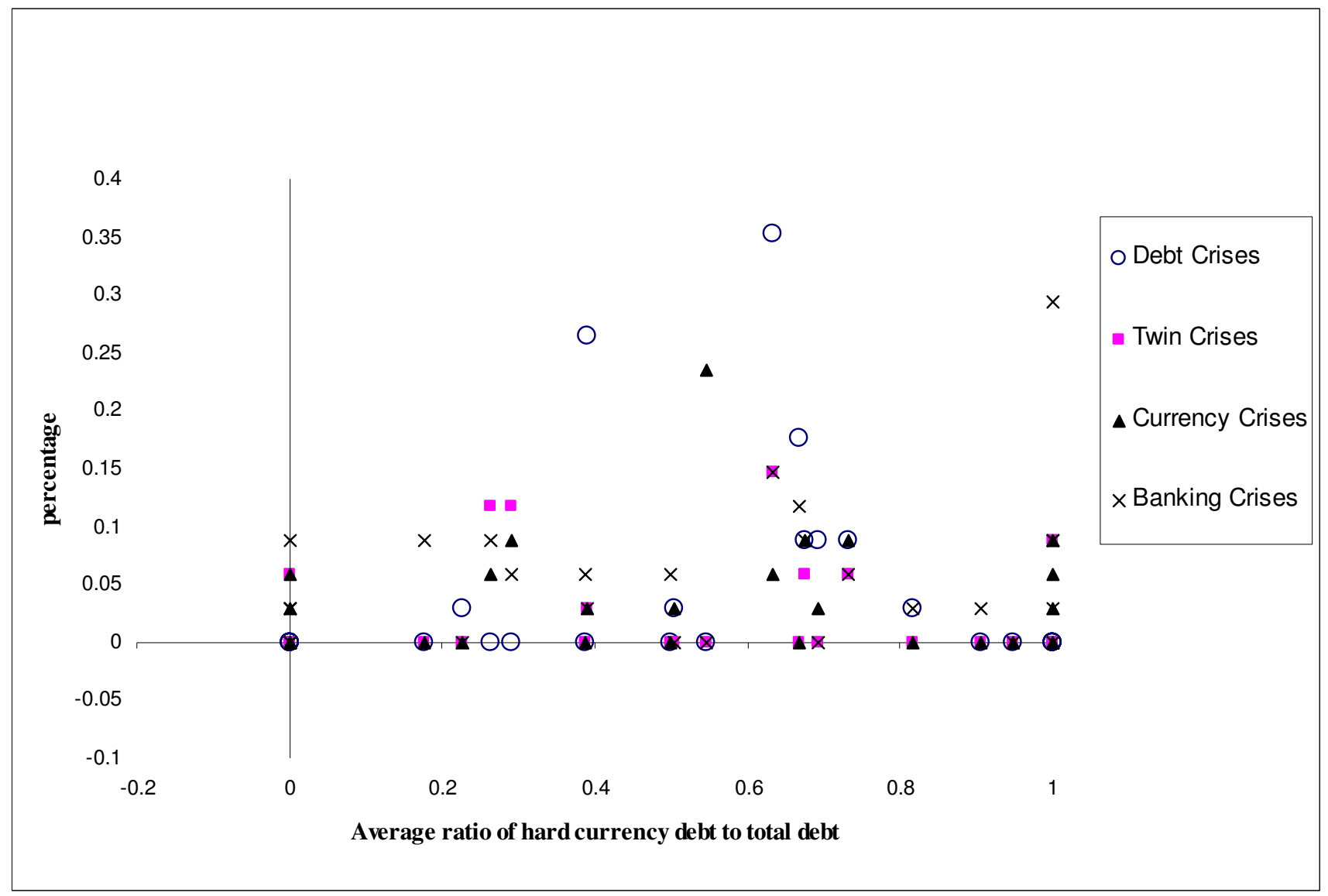

Notes: Crisis frequencies are calculated by dividing the number of years in which a country experienced a crisis by the total sample years. Both numerator and denominator exclude years of ongoing crisis. However, the debt crises series is calculated as the percentage of the period spent without a resolution of a debt default 
Figure 7 Crisis Frequencies By Country versus the Average Level of Original Sin, 1972-1997

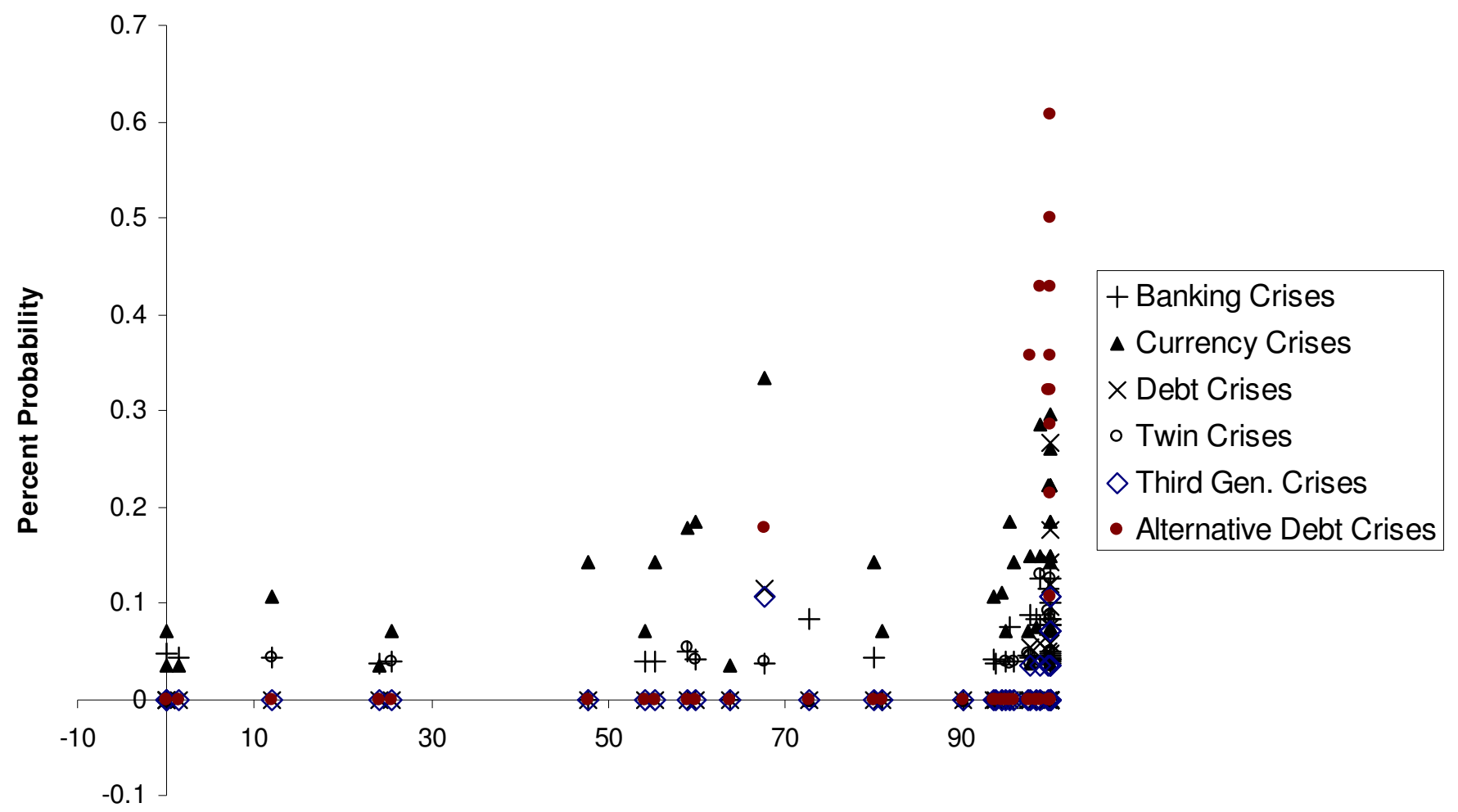

Average Original Sin Measure

Note: Crisis frequencies are calculated by dividing the number of years in which a country experienced a crisis by the total sample years. Both numerator and denominator exclude years of ongoing crisis. However, alternative debt crises is the percentage of the period spent without a resolution of a debt default. 
Figure 8 Crisis Frequencies by Country versus the Average Level of the "Mismatch" Measure, 1880-1913

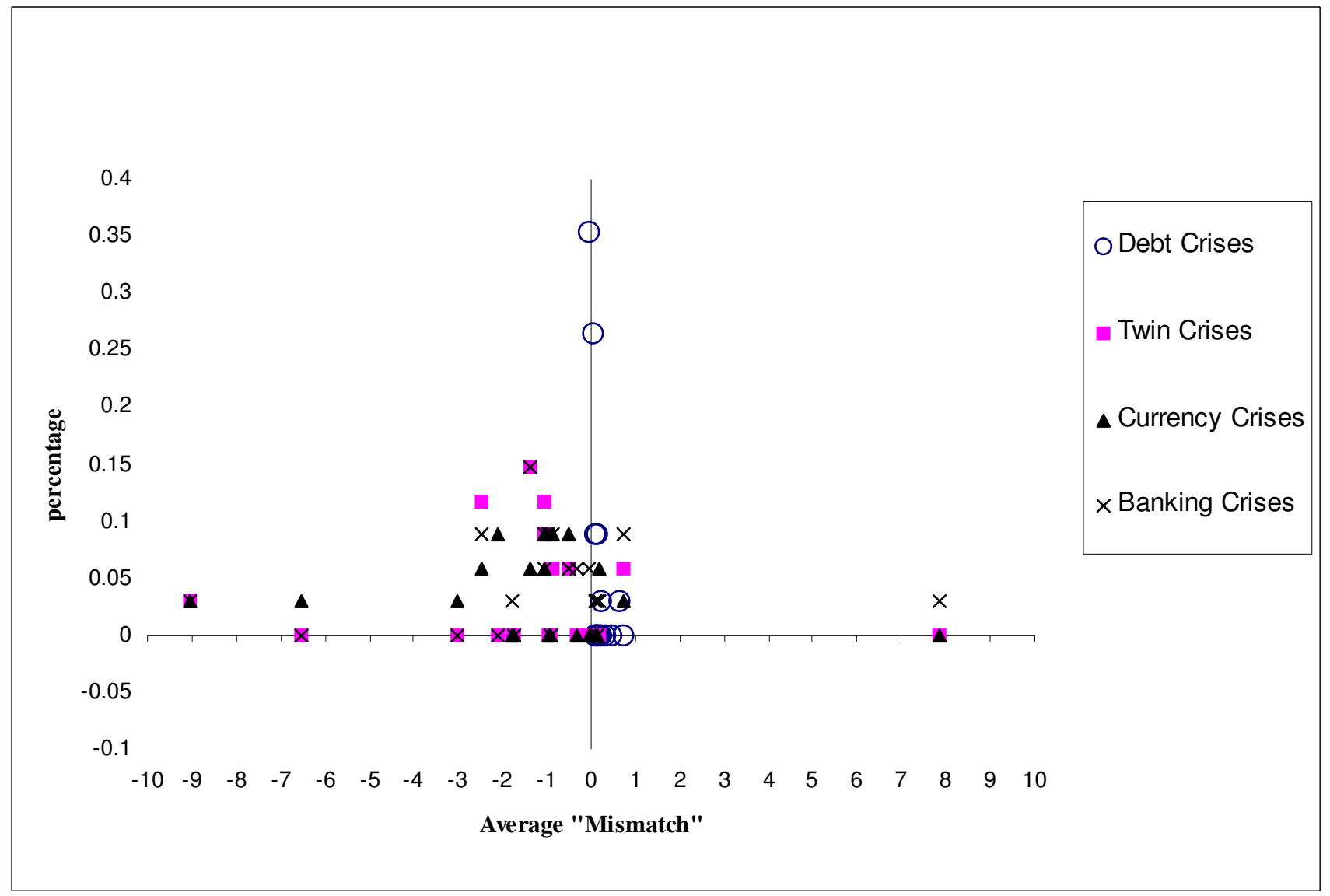

Notes: The mismatch variable for debt crises uses interest payments. The mismatch for other types of crises uses debt outstanding. See text for explanations. 
Figure 9 Crisis Frequencies by Country versus the Average Level of the "Mismatch" Measure, 1972-1997

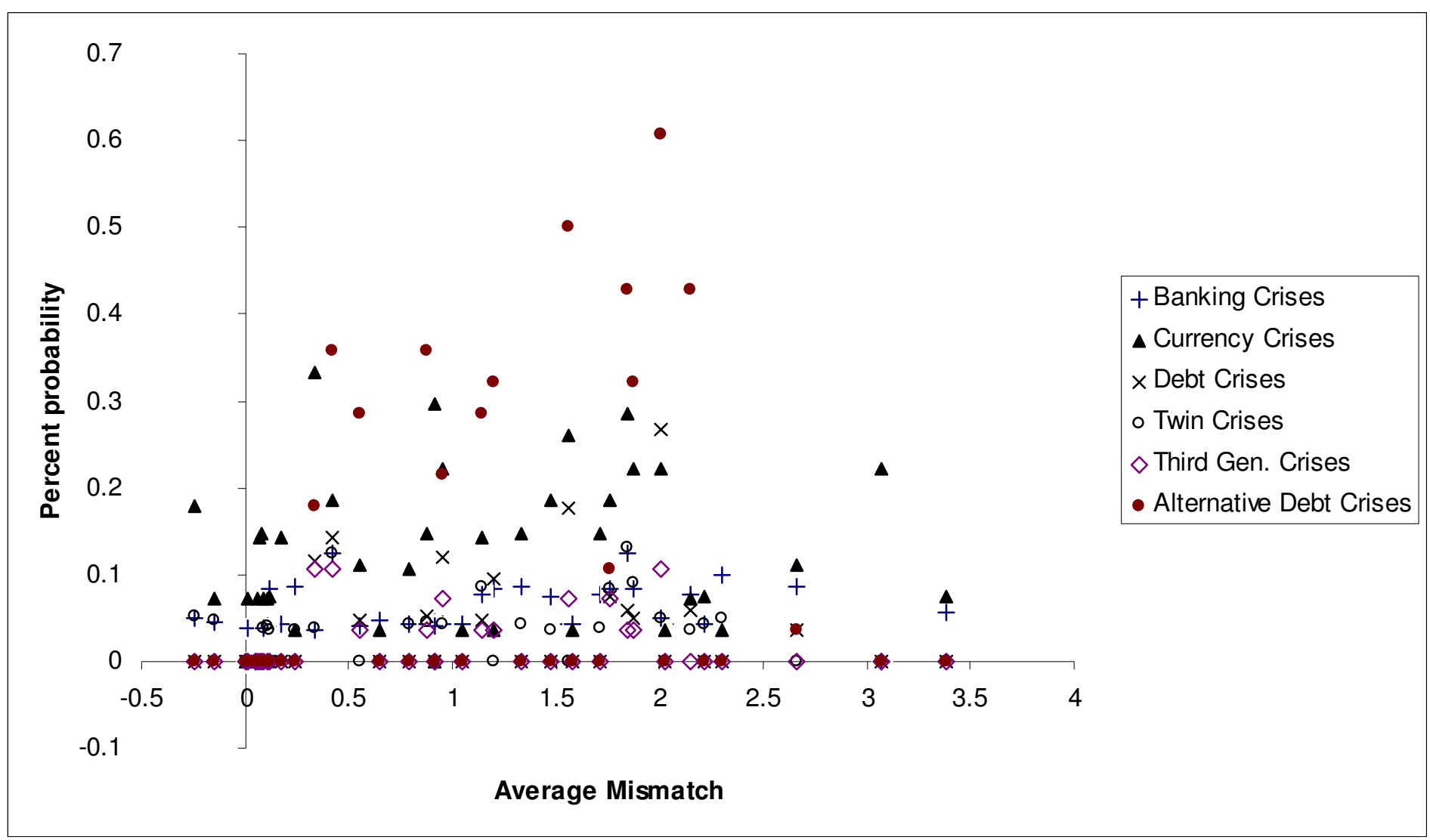

Notes: See notes to Figure 7 and text for definitions. 
Figure 10 Marginal Effect of the Ratio of Hard Currency Debt to Total Debt

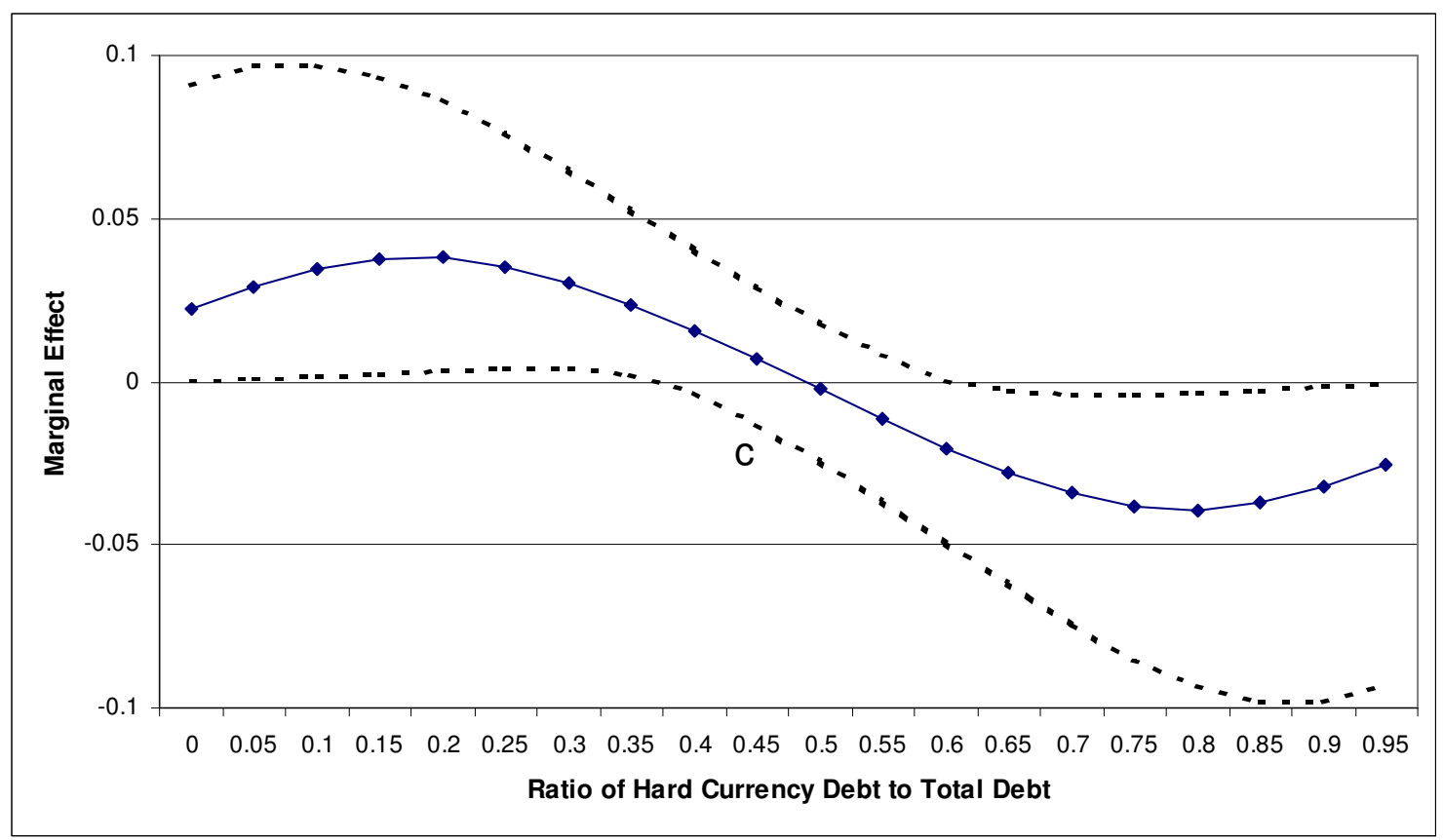

Notes: Figures are calculated based on the model in column 1 of Table 1. Currency crisis indicator equals one, lagged banking crisis equals one and other variables are at their sample means. 
Figure 11 Predicted Probabilities of a Debt Crisis, 1880-1913

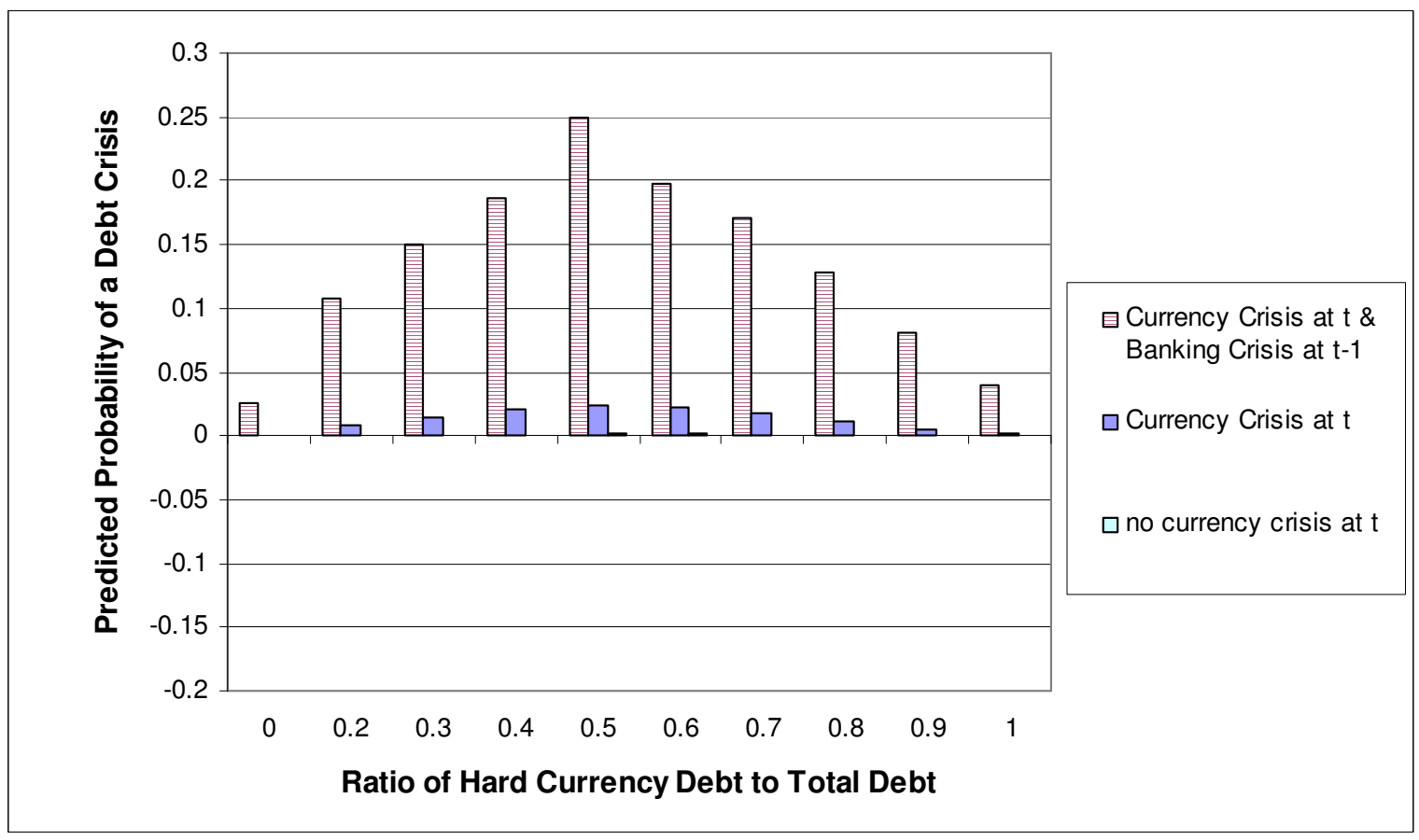

Notes: Figures are calculated based on the model in column 1 of Table 1 . The probabilities are evaluated at the sample means of the control variables with the exception of the currency crisis and banking crisis variables as indicated above. 
Figure 12 Predicted Probabilities of a Debt Crisis, 1972-1997.

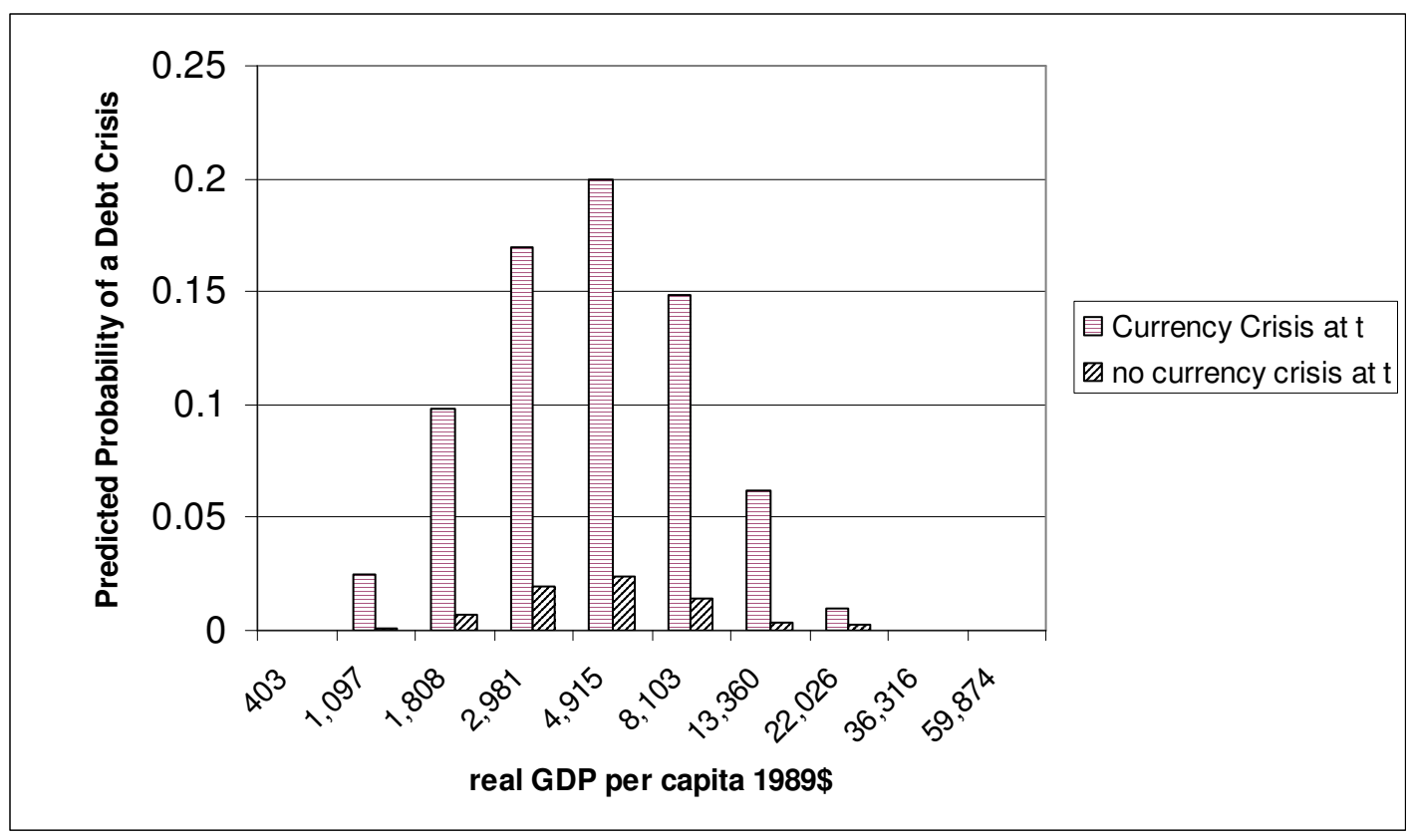

Notes: Figures are calculated based on the model in column 3 of Table 2. The probabilities are evaluated at the sample means of the control variables with the exception of the currency crisis indicator which is zero or one and output which varies as displayed. 
Figure 13 "Radar" Chart Showing the Four-Part Categorization of Countries, 19721997.

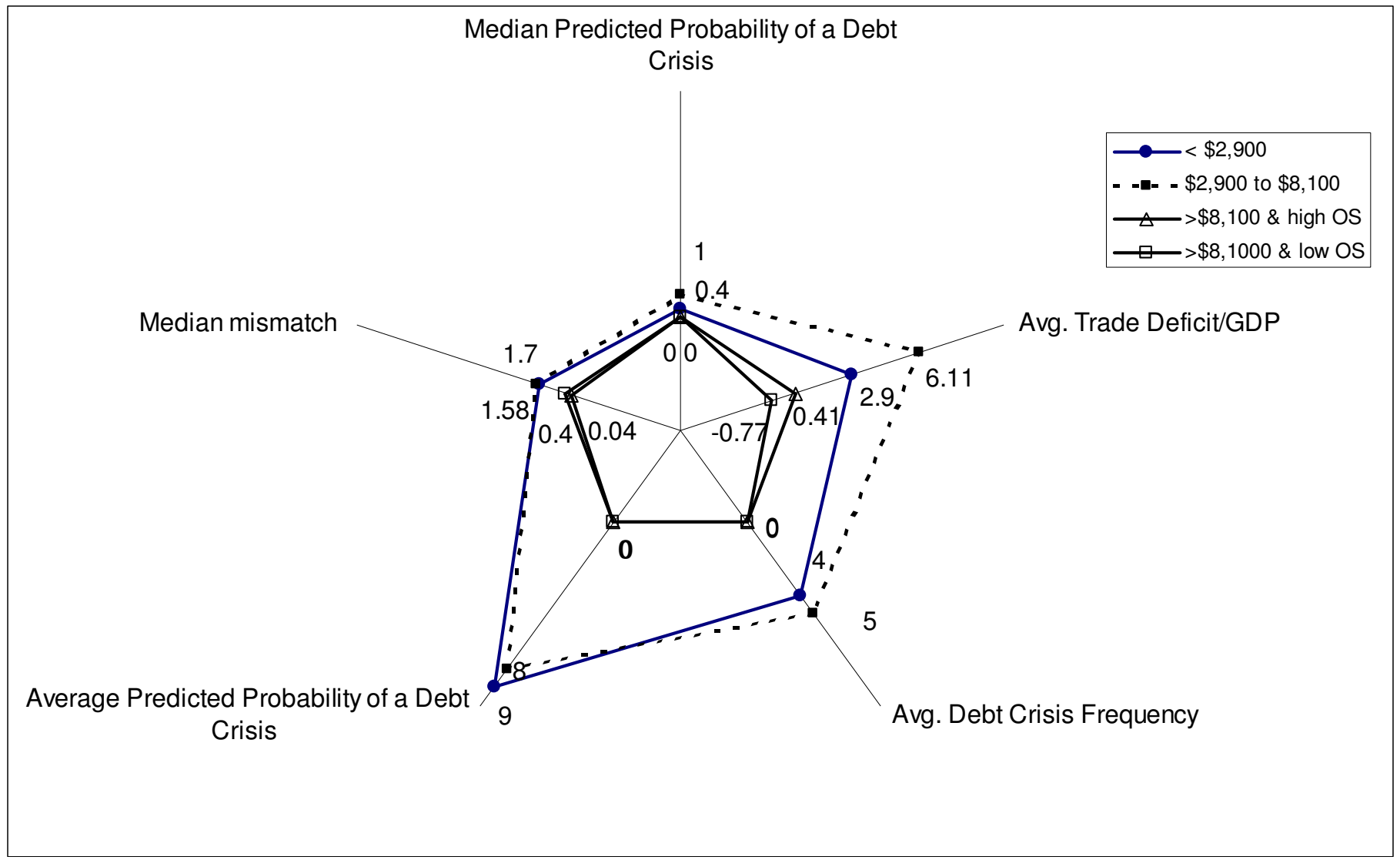

Notes: The figure shows four bands of countries. They are divided on their GDP measures. The first category being all country year observations where real GDP per capita is less than $\$ 2,900$. Low OS means an observation's average original sin was less than or equal to 20 percent. High original sin implies a measure of greater than 20 percent. All measures on each axis are on the same scale. Predicted and actual probabilities are based on the 0 to 100 scale. The predicted probabilities come from the model estimated in column 3 of Table 2. 
Figure 14 Predicted Probabilities of a Banking Crisis, 1972-1997

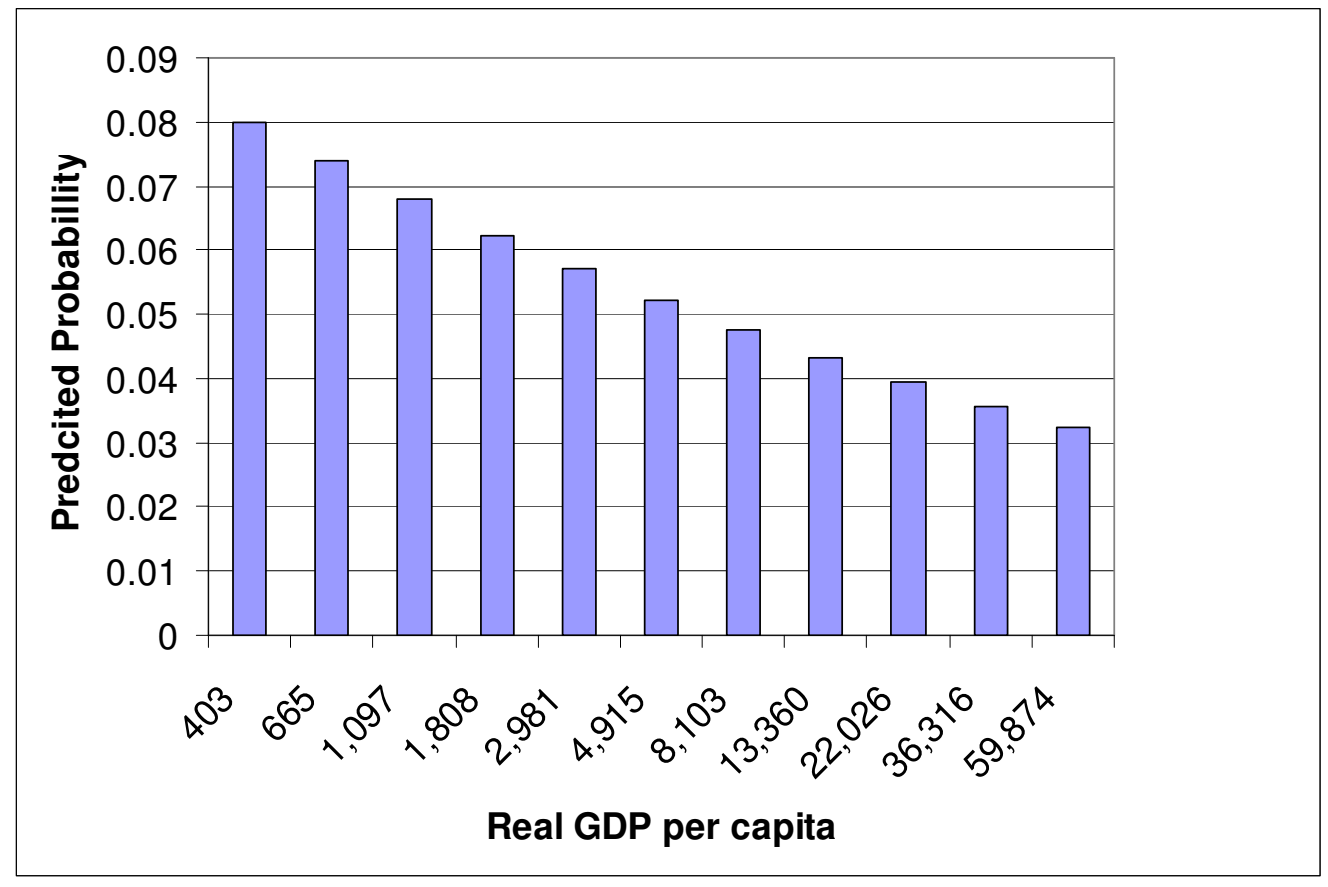

Notes: Figures are calculated based on the model in column 3 of Table 6 . The probabilities are evaluated at the sample means of the control variables with the exception of GDP per capita which varies as displayed. 
Table A.1 Crisis Dates, 1880-1913

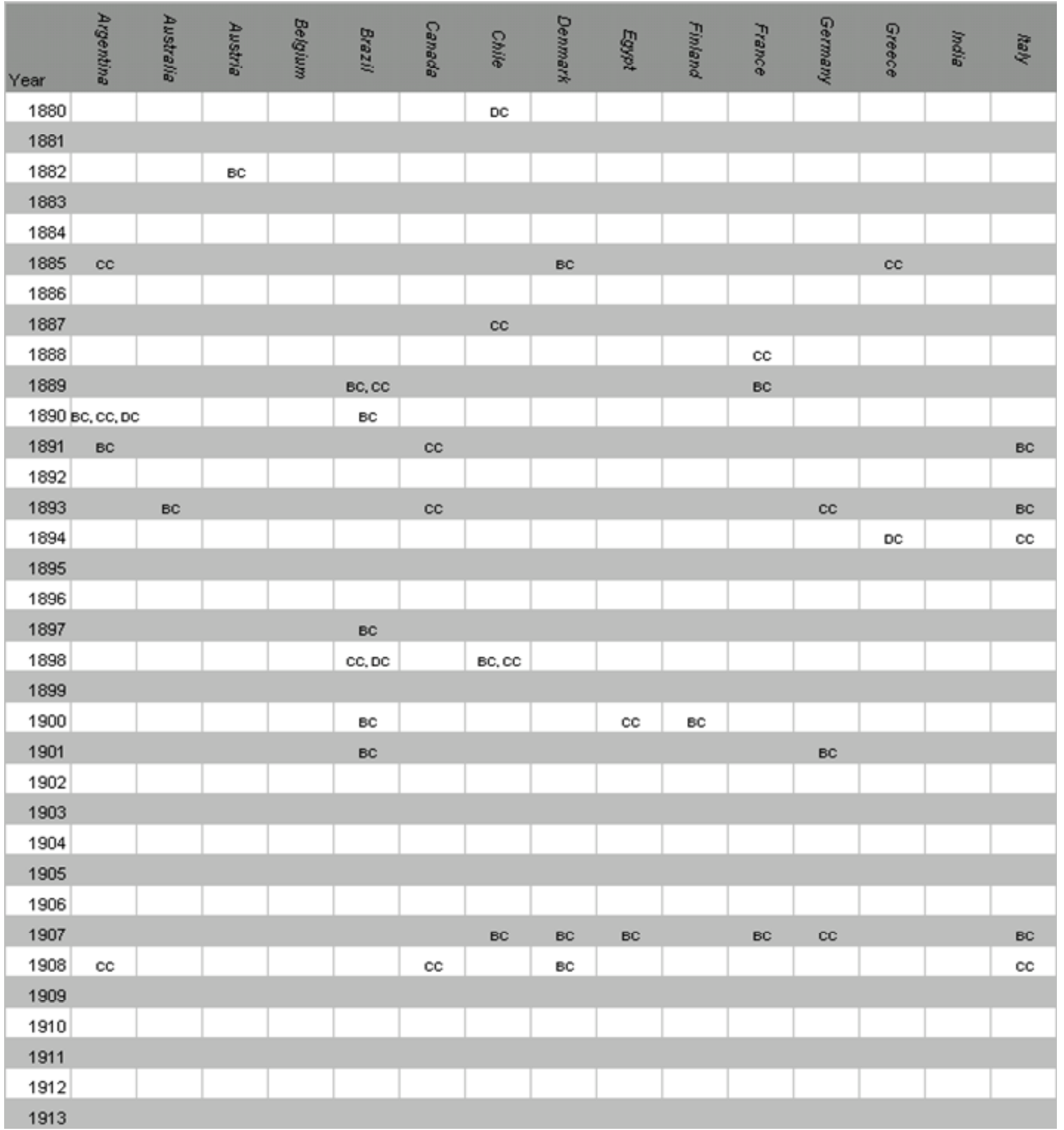


Table A.1 (continued) Crisis Dates, 1880-1913

\begin{tabular}{|c|c|c|c|c|c|c|c|c|c|c|c|c|c|c|c|}
\hline Year & 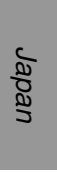 & 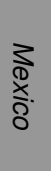 & $\begin{array}{l}\frac{Z}{0} \\
\frac{1}{2} \\
\frac{1}{2} \\
\frac{0}{3} \\
\frac{0}{2}\end{array}$ & 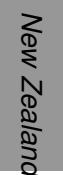 & 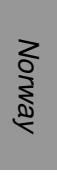 & 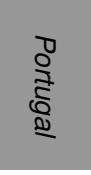 & 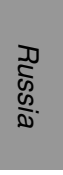 & 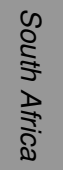 & $\begin{array}{l}\infty \\
D \\
\frac{0}{5}\end{array}$ & $\begin{array}{l}\infty \\
\sum_{\infty}^{\infty} \\
\stackrel{D}{D}\end{array}$ & 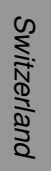 & 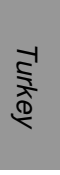 & $\stackrel{c}{\lambda}$ & ळ & 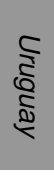 \\
\hline 1880 & & $\mathrm{DC}$ & & & & & & & & & & $\mathrm{DC}$ & & & \\
\hline 1881 & & & & & & & & $\mathrm{BC}$ & & & & & & & \\
\hline 1884 & & $\mathrm{BC}$ & & & & & & & & & & & & $\mathrm{BC}$ & \\
\hline 1885 & & & & & & & $\mathrm{DC}$ & & & & & & & & \\
\hline 1886 & & & & & & & & & & & & & & & \\
\hline 1887 & & & & & & & & & & & & & & & \\
\hline 1891 & & & & & & $\mathrm{BC}, \mathrm{CC}$ & $\mathrm{CC}$ & & & & & & & cc & DC \\
\hline 1892 & & & & & & DC & & & & & & & & & \\
\hline 1893 & & & & $\mathrm{BC}$ & & & & & & & & & & $\mathrm{BC}, \mathrm{CC}$ & \\
\hline 1894 & & & & & & & & & & & & & & & \\
\hline 1895 & & & & & & & & & & & & & & & \\
\hline 1896 & & & & & & & & & & & & & & & \\
\hline 1897 & & & $\mathrm{BC}$ & & & & & & & $\mathrm{BC}$ & & & & & \\
\hline 1898 & & & & & & & & & & & & & & & \\
\hline 1905 & & & & & & & & & & & & & & & \\
\hline 1906 & & & & & & & & & & & & & & & \\
\hline 1907 & $\mathrm{BC}$ & $\mathrm{BC}$ & & & & & & & & $\mathrm{BC}$ & & & & $\mathrm{BC}$ & \\
\hline 1908 & $\mathrm{CC}$ & & & & & & & & & & & & & & \\
\hline 1909 & & & & & & & & & & & & & & & \\
\hline 1910 & & & & & & & & & & & & & & & \\
\hline 1911 & & & & & & & & & & & & & & & \\
\hline 1912 & & & & & & & & & & & & & & & \\
\hline 1913 & & & & & & & & & & & & & & & $\mathrm{BC}$ \\
\hline
\end{tabular}

Note: CC represents currency crises, BC represents banking crises, DC represents debt crises. 
Table A.2 Crisis Dates 1972-1997

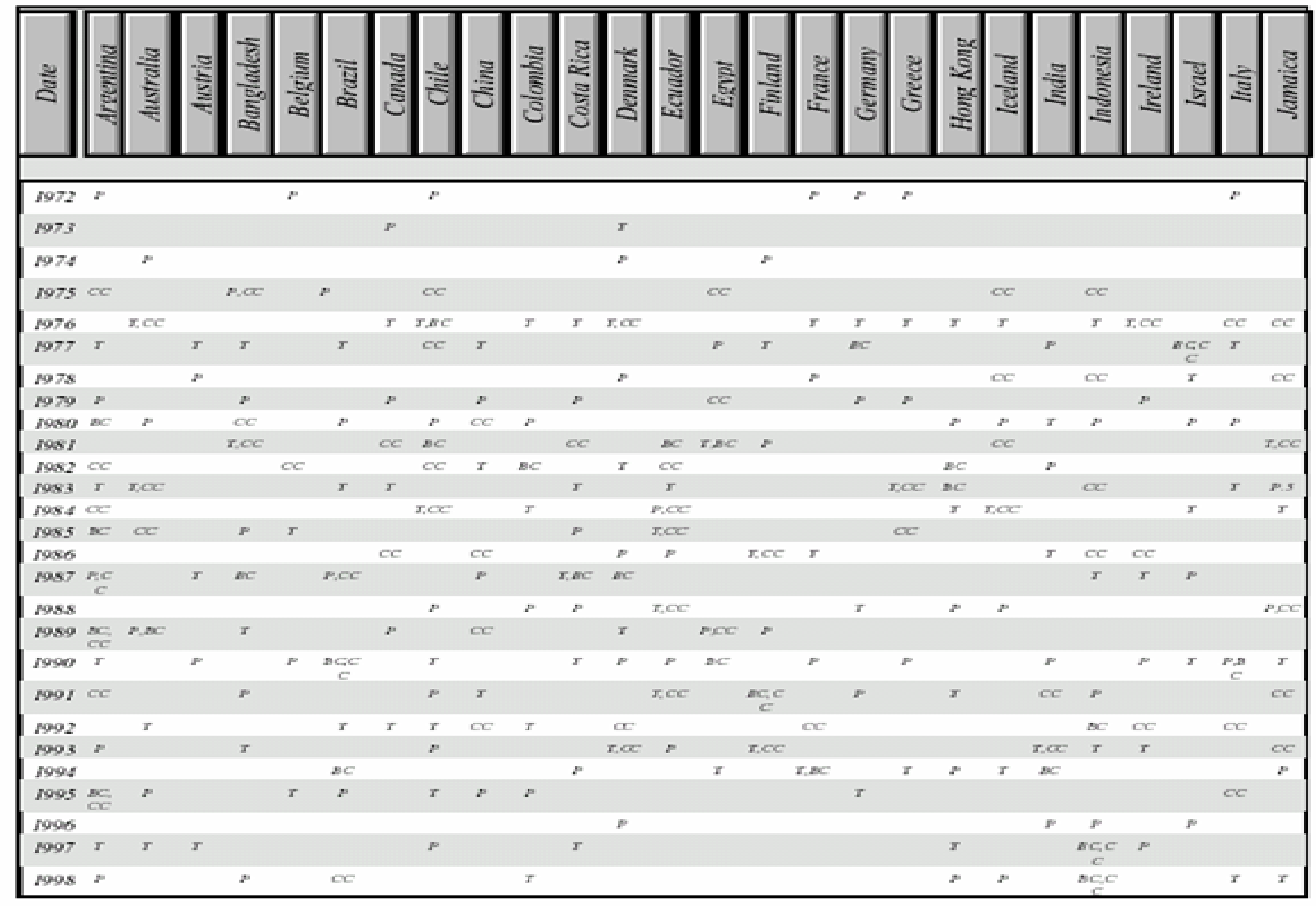

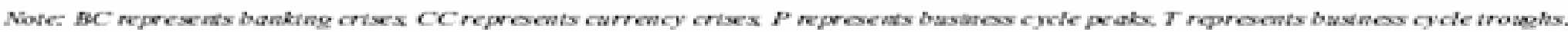


Table A.2 (Continued) Crisis Dates, 1972-1997

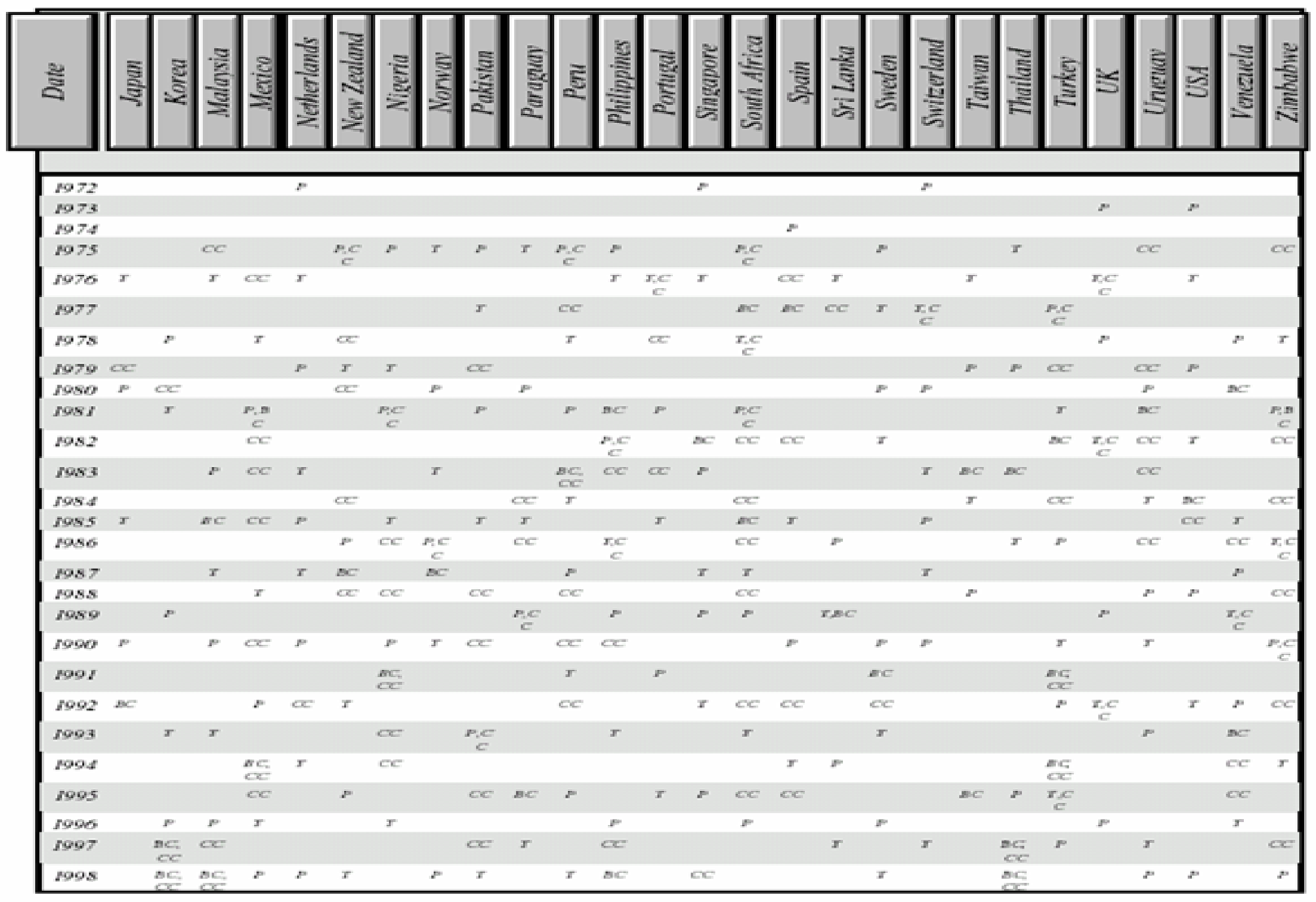

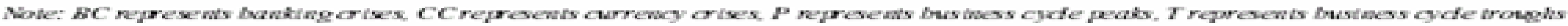


Table A.3 Countries in the Estimation Samples

\begin{tabular}{ll|ll} 
Countries in the & 1972-1997 Estimation Sample & Countries in the & 1880-1913 Estimation Sample \\
\hline Argentina & Nigeria & Argentina & Italy \\
Australia & Norway & Australia & Japan \\
Bangladesh & Pakistan & Austria & Netherlands \\
Belgium & Paraguay & Belgium & Norway \\
Brazil & Peru & Brazil & Portugal \\
Colombia & Philippines & Canada & Russia \\
Costa Rica & Senegal & Denmark & Spain \\
Cote D'lvoire & Sri Lanka & France & Sweden \\
Canada & Spain & Germany & Switzerland \\
Chile & Sweden & Greece & United States \\
Denmark & Thailand & & \\
Ecuador & Turkey & & \\
Egypt & Uruguay & & \\
Ghana & United Kingdom & & \\
India & United States & & \\
Indonesia & Venezuela & & \\
Jamaica & Zimbabwe & \\
Malaysia & & \\
Mexico & & \\
\hline \hline
\end{tabular}

